\title{
Microfinance Governance: A Systematic Review and Future Research Directions
}

\author{
Rasel, M. A. \& Win, S.
}

Author post-print (accepted) deposited by Coventry University's Repository

Original citation \& hyperlink:

Rasel, MA \& Win, S 2020, 'Microfinance Governance: A Systematic Review and Future Research Directions' Journal of Economic Studies, vol. (In-press), pp. (In-press).

https://dx.doi.org/10.1108/JES-03-2019-0109

DOI 10.1108/JES-03-2019-0109

ISSN 0144-3585

Publisher: Emerald

Copyright (C) and Moral Rights are retained by the author(s) and/ or other copyright owners. A copy can be downloaded for personal non-commercial research or study, without prior permission or charge. This item cannot be reproduced or quoted extensively from without first obtaining permission in writing from the copyright holder(s). The content must not be changed in any way or sold commercially in any format or medium without the formal permission of the copyright holders.

This document is the author's post-print version, incorporating any revisions agreed during the peer-review process. Some differences between the published version and this version may remain and you are advised to consult the published version if you wish to cite from it. 


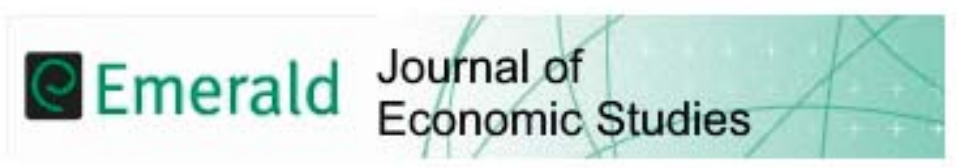

\section{Microfinance governance: a systematic review and future research directions.}

\begin{tabular}{|r|l|}
\hline Journal: & Journal of Economic Studies \\
\hline Manuscript ID & JES-03-2019-0109.R2 \\
\hline Manuscript Type: & Research Paper \\
\hline Keywords: & $\begin{array}{l}\text { Corporate governance, board of directors, microfinance institutions, } \\
\text { systematic literature review, further research directions }\end{array}$ \\
\hline
\end{tabular}




\title{
Microfinance Governance: A Systematic Review and Future Research Directions.
}

\begin{abstract}
Purpose: The purpose of this article is to systematically review extant research on the corporate governance of microfinance institutions (MFIs) from a global perspective. In the process, it discusses scholarly contributions and highlights key issues from the findings of past studies on several governance attributes, in particular, their interconnections and influence on different institutional outcomes of the sector.
\end{abstract}

Design/Methodology/Approach: Although academic work on microfinance governance is substantial, prior studies lack a comprehensive approach to reviewing the literature on this topic. We adopted a systematic method to review past studies on microfinance corporate governance, applying particular inclusion and exclusion criteria. In this regard, the study developed specific questions and sought to find their answers from existing literature.

Findings: The findings from our research indicate that microfinance governance and performance relationship are central focuses of the majority of our reviewed papers, although a few attempts have been made to explain the interconnection between corporate governance (CG) mechanisms at the firm and institutional level. Our findings also show that existing studies use a variety of techniques to measure MFI performance vis-à-vis their hybrid mission, such as profitability and outreach. Moreover, the study found that common topics discussed in the mainstream literature include board structure, CEO characteristics, audit quality, external governance, disclosure and MFI ownership type.

Limitations/Implications: This review has some limitations that warrant further research. First, we considered only peer-reviewed scientific publications for our systematic review. Second, we omitted non-English journal papers from our sample. In light of these limitations, we provide some future research directions that may shed further light on our current inquiry.

Originality/Value: This paper evaluates past relevant studies using a systematic approach (in preference to the commonly used narrative approach) for a span of over eighteen years; thereby contributing significantly to sectoral governance literature. This study is novel in that it offers new incentives and opportunities for further research in order to meet the shortcomings of reviewed papers from various theoretical, empirical, methodological and geographical standpoints.

Keywords: Corporate governance, board of directors, microfinance institutions, systematic literature review, further research directions.

Paper type: Research paper.

\section{Introduction}

Microfinance has emerged as a tool for economic development, intended to serve low-income people with financial needs (Ledgerwood, 1999). It mainly targets low-income communities from developing economies where rates of financial penetration are low as compared with the developed world (Chiu, 2015). These poor groups are often excluded from mainstream banks as they cannot meet prevailing 
interest rates and collateral requirements and/or the costs associated with screening and monitoring activities are too high to make lending to this group profitable (Hermes and Lensink, 2007). For this reason, Professor Muhammad Yunus, a Bangladeshi economist, founded the Grameen Bank in Bangladesh in the 1970s to include poor communities in finance, enabling them to set up small rural enterprises through the provision of tiny loans (Yunus, 2003). The efforts of Yunus and Grameen Bank in creating socioeconomic development from the grassroots earned them the Nobel Peace Prize in 2006 (Kono and Takahashi, 2010; Sengupta and Aubuchon, 2008).

There are various developmental categories that MFIs consider for the socio-economic development of poor communities. For social development programmes, MFIs play a major role in health improvement, housing, child schooling, gender equality and women's empowerment. On the other hand, for economic development programmes, MFIs also contribute to the promotion of micro-enterprises for income generation and employment creation, leading to poverty alleviation. All in all, programmes implemented by MFIs indicate that microfinance is an effective instrument for global financial inclusion. Microfinance has achieved global recognition in recent decades as an important tool for household security, microenterprise development and poverty alleviation (Tilakaratna and Hulme, 2015). The proponents of microfinance also suggest that the exponential growth of the industry has contributed significantly to improved social welfare (Khandker, 2005), job creation (Raihan et al., 2017), enterprise development and the general financial health of most economies (Adams and Tewari, 2017).

The rapid structural transformation of the sector has become a perennial debate among academics and other microfinance stakeholders and modern microfinance institutions are guided by multiple institutional logics. A development or social-welfare logic encourages MFIs to alleviate poverty, consider clients as beneficiaries and scale up the welfare impact of donor funds, whereas financial logic motivates MFIs to maximise profit and treat beneficiaries as customers and sources of income, while meeting fiduciary obligations to stakeholders (Shahriar et al., 2015). These two distinct logics are together known as the 'dual bottom line' of microfinance organisations (Battilana and Dorado, 2010; Im and Sun, 2015; Zulfiqar, 2017). In addition to development and banking logic, the industry has recently started to consider its 'third bottom line', namely, environmental performance (Allet, 2014; Allet and Hudon, 2015; Forcella and Hudon, 2016). Achievement of these goals in what is a highly competitive market can be linked to many explanatory factors, among which, effective corporate governance is a critical one.

Corporate governance has evolved as a system to appropriately control, monitor and manage firms, in particular, following major corporate collapses and failures. As such, the relative importance of corporate governance practice has been widely recognised by different business entities in recent times. Corporate governance principles have been drawing more attention from academics and practitioners in the last few years, particularly focussing on the long-term sustainability and institutionalisation of microfinance firms (Labie, 2001). There are several important reasons for this trend, as proposed by Labie and Mersland (2011). For instance, the tremendous growth in various types of service providers, institutional transformation of MFIs, legal changes, the shift from single to multiple product offerings in similar vein to conventional banks, the emergence of liabilities management, more proactive policies by public authorities for the development of the industry and global recognition all explain why microfinance governance is an interesting research topic. These are some major contributing factors that put governance at the forefront of the microfinance policy debate. 
Corporate governance at the level of the firm entails a variety of mechanisms. These mechanisms can be split into two broader categories, namely, external and internal (Habib and Jiang, 2015; Weir et al., 2002). The former encompasses external stakeholders in the boardroom, regulation, competition, external auditing and country governance indices, whereas the latter comprises characteristics of the internal board directors, the chief executive officer (CEO), board independence, internal auditing, internal stakeholders and capital structure. Although the literature on corporate governance is abundant in other sectors, studies on this concept are limited albeit growing in the microfinance sector. Even the governance practice from other sectors may not be fully replicated in the microfinance field due to the complexity of the regulatory structure. Further, existing studies on microfinance governance have shown fragmented and mixed findings. Given the significant role of microfinance governance, it is necessary to obtain an improved understanding of research developments in this area.

Our paper is unique as we systematically review past relevant studies, rather than take a traditional 'narrative' review approach, which has hitherto been adopted exclusively by scholars in this field. Hence, systematic knowledge of the corporate governance structure of MFIs is missing from existing studies. To move beyond what is already known, we delve deeper into existing academic work and seek to find what is de facto not known about the subject. The rest of the paper is organised as follows. In the second section, we provide a historical overview of microfinance institutions, followed by the third section, where we explain the methodology used to review the literature. In the fourth section, we present the findings of our study. Last but not least, we highlight some gaps in the literature from selectively chosen studies and suggest several areas for further investigation in the fourth and fifth sections respectively.

\section{Historical Overview of Microfinance Institutions}

Although the concept of modern microfinance relates to the inception of the Grameen model in Bangladesh, little is known about when this system originated (Mia et al., 2019). However, the evolution of a concept such as this can be traced back several centuries. In the early $1500 \mathrm{~s}$, it is claimed that the creation of pawnshops replaced usurious money lenders in Europe (Helms, 2006). Formal financial institutions have also been around for generations, providing credit and saving services to the unbanked poor in Europe. In the 1720s, Jonathan Swift, a renowned Irish nationalist, established the Irish loan fund system, which intended to provide credit to the poorest populations in Ireland (Hollis and Sweetman, 2001). After a century of gradual progress as an informal credit institution, the loan fund system saw a surge in growth from 1823. This system had around 300 funds throughout the country by the 1840 s (Helms, 2006) and reached out to approximately $20 \%$ of household borrowers annually, making it one of the most successful institutions for microfinance in the world (Hollis and Sweetman, 2004). However, due to the financial repression, the system eventually went bankrupt in the 1950s (Seibel, 2005). The Irish loan fund system therefore consists of three phases of history: 1) slow growth for a century; 2) rapid expansion for a few decades and finally; 3) gradual decline for a century due to the financial repression, resulting in the loss of business.

While the Irish loan fund system is one early example of financial inclusion, microfinance also has origins in some other countries as well, including Germany, India, Indonesia, Nigeria and Pakistan (Mia et al., 2019). In Africa and Nigeria, microfinance existed in the 1600s in the shape of ajo and esusu - the rotating saving and credit associations (RoSCA) (Mia et al., 2019; Seibel, 2005). It is also claimed that modern microfinance originated in Germany (Morduch, 1999). Evidence suggests that the first credit cooperative was founded in Germany by Friedrich W. Raiffeisen in 1864 (Guinnane, 
2001). Since then, the cooperative expanded rapidly in the country, followed by other developed and developing nations in Europe, North America and other parts of the world (Helms, 2006). The main objective of the German credit cooperative was to free rural people from the grasp of moneylenders and improve their welfare.

In Indonesia, the establishment of People's Credit Banks (BPRs) in 1895 is another early example of the microfinance revolution. These banks became the largest microfinance system in the country, comprising 9,000 branches (Helms, 2006). In the early 1900s, both private banks and government agencies ran rural finance interventions in Latin America to modernise the agricultural sector, raise investment through credit, mobilise savings and diminish abusive lending practices. The period between 1950 and 1970 was also remarkable when donors and governments provided agricultural loans to small farmers in an effort to enhance productivity and incomes (Helms, 2006). In this era, both state-owned and farmer cooperatives were actively involved in credit support programmes for farmers, although these development banks eventually failed and lost their capital due to poor repayment performance.

The era of the 1970s marked the birth of modern microfinance when Grameen Bank and ACCION International began to provide small credit to petty traders in South Asia and Latin America (Chiu, 2015). Nowadays, countless organisations aim to replicate the success of these two pioneering organisations and the Grameen banking model, in particular, has enjoyed much popularity across the globe. In the late 1990s, there was an emergence of Islamic MFIs in Asia that offered interest-free loans to the poor through a profit-sharing credit system, which has also become an effective tool for poverty alleviation. Overall, it is well understood that the subsequent evolution of microfinance and other related schemes, for example, credit unions and cooperatives, shaped modern microfinance today, after centuries of experience from trial and error; failure and success (Mia et al., 2019).

It is important to note that since the inception of Grameen Bank, the growth of the industry has been unprecedented (Rajbanshi et al., 2015). For instance, the 2013 report of the microcredit summit campaign shows that between 1997 and 2010, the total number of clients served by MFIs worldwide grew continually from 13 million to 205 million. Further, the number of poorest customers receiving microfinance services for the first time grew from 8 million to 138 million (Tchakoute-Tchuigoua et al., 2017). The continued proliferation of the microfinance industry and its size will allow the sector to become the largest global banking market in relation to the number of clients (Mersland, 2013).

\section{Methodology}

Given the need for our study, we applied a systematic review method proposed by Tranfield et al. (2003). The systematic review helps spot major scientific contributions to a research field or question (Becheikh et al., 2006). Unlike the traditional narrative review approach, systematic review deals with the issue of researcher bias by applying transparent, reproducible and iterative review processes and uses a comprehensive framework of searching that combines wider database searching, crossreferencing between scholars and the application of agreed exclusion criteria (Phillips et al., 2015; Tranfield et al., 2003). Using pre-specified quality criteria, we assessed all relevant studies and extracted findings considered to be of 'good enough' quality (Van Rooyen et al., 2012). We conducted this rigorous method on a set of scientific publications, from which we identified key areas of concern and proposed potential ways forward to advance research in microfinance governance. 


\subsection{Systematic Review Procedure}

As proposed by Tranfield et al. (2003), a systematic review procedure in the management field entails an established three-stage formula. Each stage includes several steps (see Figure 1) but, as per the necessity of our study, we customised these steps to best suit our review procedure. This formula has been adopted and tested by other management and governance studies (Ahmad and Omar, 2016; Albliwi et al., 2015; e.g. Crossan and Apaydin, 2010). We explain these steps in the subsequent section.

\subsubsection{Research Purpose}

\begin{tabular}{|c|c|c|}
\hline$\subsetneq$ & Three-Stage Procedure & $\nabla$ \\
\hline Planning the Review & Executing the Review & Documenting the Review \\
\hline $\begin{array}{l}\text { - Research purpose } \\
\text { - Research protocol } \\
\text { development }\end{array}$ & $\begin{array}{l}\text { - Literature search } \\
\text { - Criteria application } \\
\text { - Study quality } \\
\text { - assessment } \\
\text { - Data extraction } \\
\text { - Data synthesis }\end{array}$ & $\begin{array}{l}\text { - Reporting } \\
\text { - Dissemination }\end{array}$ \\
\hline
\end{tabular}

Figure 1: Necessary steps for review procedure (adapted from Tranfield et al. (2003).

We aimed to synthesise and integrate current research on MFI governance from a global standpoint in a systematic manner. Following that, we then posed two important research questions: $R Q 1$. What does the overall literature show regarding the current state of microfinance governance research? $R Q 2$. What are the paths available for future scholars to further develop and extend the current body of literature in this domain?

Our study makes some important contributions to the body of academic knowledge in the following ways. Firstly, our study is the first to summarise and combine reliable findings of germane studies using a scientific method. Secondly, we articulate the significance and relevance of existing research. Finally, we highlight key areas that are missing from the extant literature and recommend they be further investigated.

\subsubsection{Research Protocol Development}

Following the guidelines of Tranfield et al. (2003), we developed our research protocol by taking into consideration several steps under the execution procedure of systematic review:

\subsubsection{Search Strategy}

Our literature search scope was limited to seven leading electronic databases, namely, EBSCO host, Emerald, Google Scholar, Science Direct, Springer Link, Taylor \& Francis and Wiley Online Library. We judged these databases to be the best academic sources of relevant articles and they provided us with access to a large stream of scholarly contributions in the domain of business and management, economy, accounting and finance. We accessed all materials on these databases through our University learning resource centre. The search strings applied to identify relevant papers from the above sources included the following keywords: ("microfinance") AND ("governance" OR "governance quality" OR "board structure" OR "ownership structure" OR "disclosure practice" OR "audit quality" OR "capital structure"). We decided on these keywords after a discussion and preliminary review of titles and abstracts of some papers. 
The search strings initially hit a sample of 342 results, as shown in Figure 2. We used similar keywords for each of the preferred databases. We did not use any particular time frame for publications as part of our search criteria since we believed that time restrictions could limit the chance of including relevant studies in our review. By extending the period for the literature search, we made efforts to include as many relevant papers as possible and keep systematic bias at a minimum. Our search string identified relevant and good quality studies from the year beginning 2001 and ending mid 2019 (see Figure 3). We could not go beyond 2019 since it was the year we accomplished our systematic review for publication.

\subsubsection{Criteria Application}

Following the guidelines of Tranfield et al. (2003) and consistent with prior review studies in different management disciplines, we applied criteria from existing papers to be sampled for our review. We chose articles that met all the selection criteria outlined in Table I. Some book chapters were also considered for this review. We determined the relevance of studies by reading their titles, abstracts and, in all cases, full article texts. At this stage, we were able to single out 75 relevant articles for review from an initial pool of 342 studies. We did not simply judge the relevance of studies against general review criteria but rather, continued with the selection process by appraising the quality of studies in accordance with the quality assessment criteria, as discussed in the next stage.

Table I. Literature Search Criteria

\section{Inclusion Criteria}

- Papers published in peer-reviewed journal outlets

- Papers that purely address all or a few MFI governance variables

- Papers written in English

\section{Exclusion Criteria}

- Non-relevant articles

- Papers that are not within the parameter of MFI governance

- Grey literature (e.g. reports, magazines, conference papers, policy statements, theses)

- Non-academic materials such as websites and social media

\subsubsection{Study Quality Assessment}

The aim of quality appraisal is to assess the validity of the selected studies, give an appropriate justification and provide the reader with sufficient information to identify if the review is applicable to their own research (Christofi et al., 2017). However, a major challenge in developing a systematic review methodology is the difficulty in designing and conducting a quality assessment of studies (Tranfield et al., 2003). This could be because there is no universally accepted homogeneous tool for appraising the quality of studies. Nevertheless, we applied a simple method of checking the quality of selected studies deemed relevant. Following the Ahmad and Omar (2016) study, we selected articles from journals that are either indexed by Scopus, Web of Science or both. This process led to the selection of high-quality peer-reviewed publications. WoS records peer-reviewed journals in the social sciences and is one of the most comprehensive databases (Crossan and Apaydin, 2010). On the other hand, Scopus has been used because of its broader coverage of relevant and quality publications. Both databases overlap and complement each other (Meho and Rogers, 2008). By applying this process, we were able to finalise our study sample, which ultimately numbered 68 articles. 


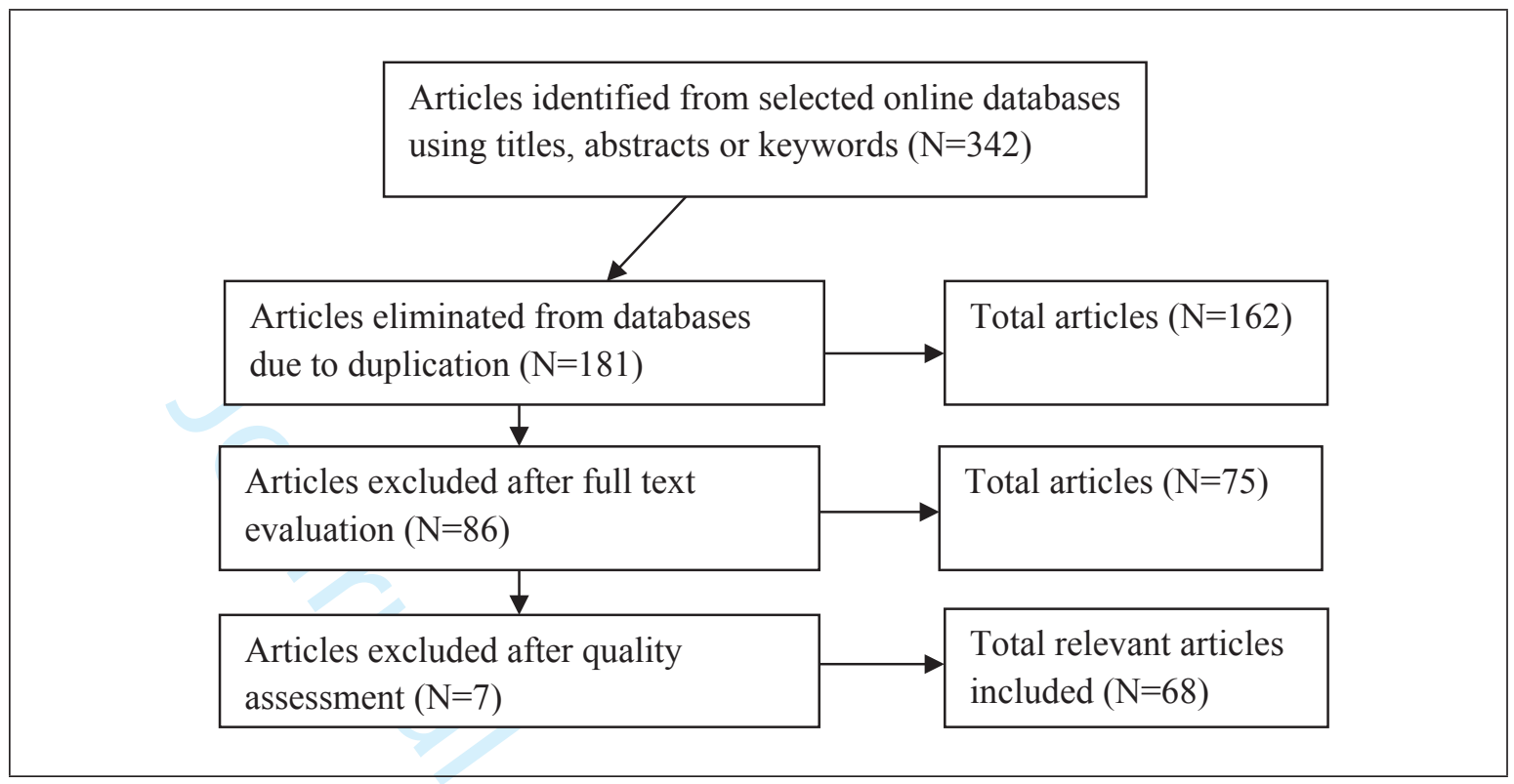

Figure 2. Article Selection Process

\subsubsection{Data Extraction}

After the quality appraisal, we extracted data from the selected studies in order to minimise human error and bias (Tranfield et al., 2003). We inserted the extracted data into excel spreadsheets, which recorded information about the author/s, the year of the study, the article title/research question, research design/data, the theory and a summary of study's results (Appendix: Table V). Both authors of this review jointly agreed upon the data extraction process and ensured the information derived through the process met the purposes of the study.

Table II. List of Journal Outlets

\begin{tabular}{|l|l|r|}
\hline Journal Name & Abbreviation & No of Articles \\
\hline Annals of Public and Cooperative Economics & APCE \\
Business \& Society & BS \\
Canadian Journal of Administrative Sciences & CJAS \\
Corporate Governance: An International Review & CGIR \\
Corporate Governance: The International Journal of Business in & CG & 1 \\
Society & & 1 \\
Corporate Ownership and Control & COC \\
DECISION & D & 4 \\
Emerging Markets Finance \& Trade & EMFT & \\
Entrepreneurship, Theory and Practice & ETP & 2 \\
European Financial Management & EFM & 1 \\
Eurasian Economic Review & EER & 1 \\
Global Business Review & GBR & 1 \\
International Business Review & IBR \\
International Journal of Emerging Markets & IJEM & 1 \\
International Journal of Social Economics & IJSE & 1 \\
International Review of Economics \& Finance & IREF & 1 \\
International Review of Financial Analysis & IRFA & 1 \\
Journal of Accounting in Emerging Economies & JAEE & 2 \\
\hline
\end{tabular}




\begin{tabular}{|c|c|c|}
\hline Journal of Accounting \& Organizational Change & JAOC & 2 \\
\hline Journal of Asian Economics & JAE & 1 \\
\hline Journal of Banking \& Finance & JBF & 3 \\
\hline Journal of Business Economics and Management & JBEM & 1 \\
\hline Journal of Cleaner Production & $\mathrm{JCP}$ & 1 \\
\hline Journal of Economics, Finance and Administrative Science & JEFAS & 1 \\
\hline Journal of Emerging Market Finance & JEMF & 1 \\
\hline Journal of Economic Studies & JES & 2 \\
\hline Journal of Economic Surveys & JES & 1 \\
\hline Journal of Family Business Management & JFBM & 1 \\
\hline Journal of International Development & JID & 2 \\
\hline $\begin{array}{l}\text { Journal of International Financial Markets, Institutions and } \\
\text { Money }\end{array}$ & JIFMIM & 1 \\
\hline Journal of Management \& Governance & JMG & 2 \\
\hline Journal of Management Studies & JMS & 1 \\
\hline Management Decision & MD & 1 \\
\hline Managerial Finance & MF & 1 \\
\hline Strategic Change & $\mathrm{SC}$ & 5 \\
\hline Quarterly Review of Economics and Finance & QREF & 3 \\
\hline World Development & WD & 3 \\
\hline Small Business Economics & SBE & 1 \\
\hline South African Journal of Economic and Management Sciences & SAJEMS & 1 \\
\hline South Asian Economic Journal & SAEJ & 1 \\
\hline Sustainable Development & SD & 2 \\
\hline & & Total $=64$ \\
\hline
\end{tabular}

Table III. List of Books/Book Chapters

\begin{tabular}{|l|l|r|}
\hline Book/Book Chapter Publishers & Publication Type & No. of Publications \\
\hline Edward Elgar Publishing Ltd. & Book Chapter & 2 \\
Nova Science Publishers, Inc. & Book Chapter & 1 \\
World Scientific Publishing & Book Chapter & 1 \\
\hline & & Total = 4 \\
\hline
\end{tabular}

\section{Reporting and Dissemination of Findings}

In this section, we present the findings of past reviewed studies by addressing our first review question (RQ1). The findings reflect information about the rise in academic publications, methodological application, geographical distribution, theoretical lenses and key governance mechanisms, as well as antecedents to and consequences of MFI governance examined by past studies.

\subsection{Rise in Academic Publications}

We gathered data from a number of scientific publications in our research domain, covering a time frame of more than one and a half decade. We identified that the earliest article in the review was published in 2001. From that time onward, there has been a considerable rise in the number of academic publications on microfinance governance (see Figure 3). Even though the number of 
publications was relatively low between 2001 and 2011 (indicating just over one scholarly article on average per year), the majority of papers were published between 2014 and 2018. This trend indicates that scholars are increasingly becoming interested in microfinance governance research.

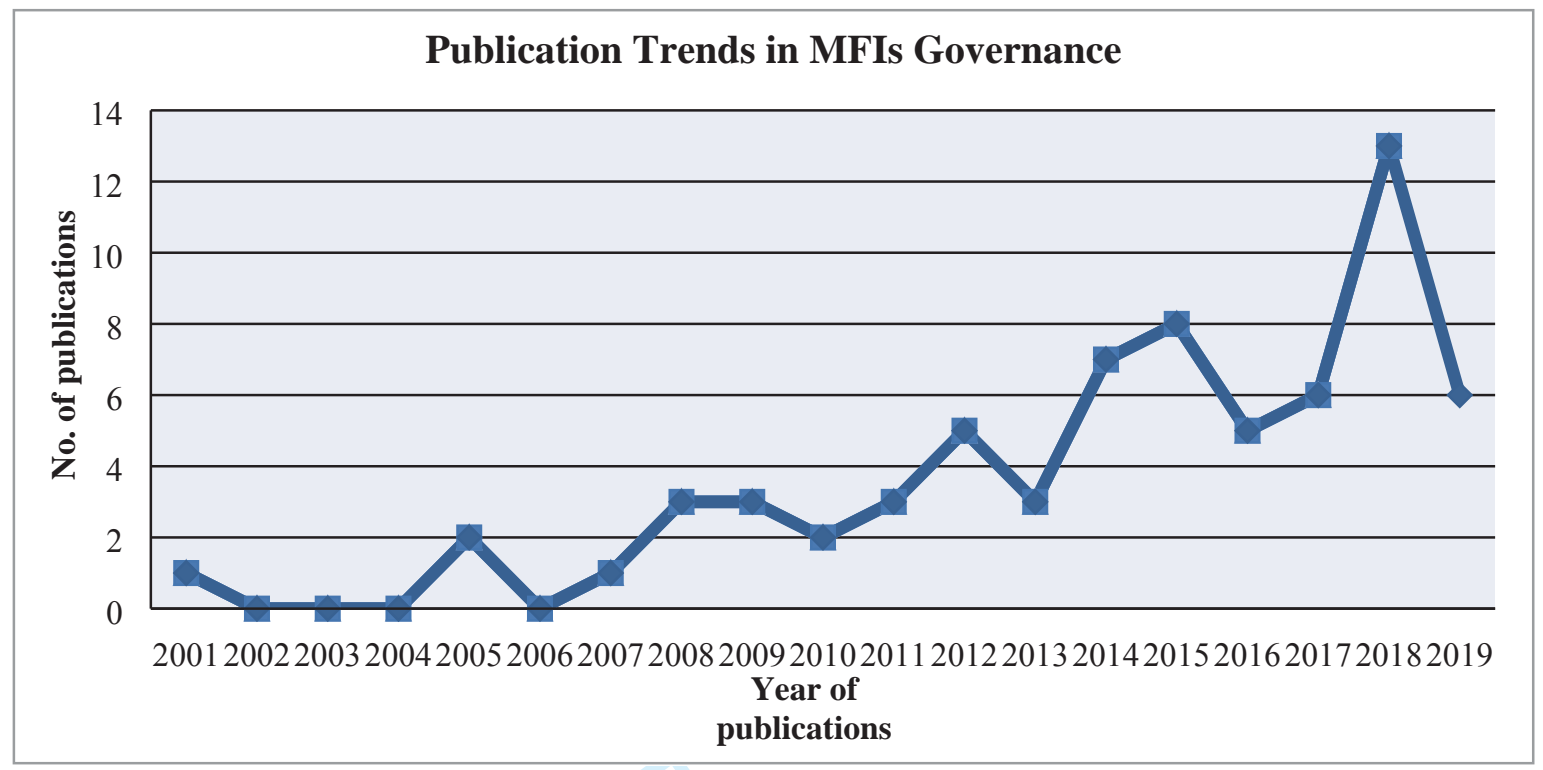

Figure 3. Rise in Publications on Microfinance Governance

\subsection{Methodological Application}

As shown in Figure 4, the majority of the reviewed articles are based on a positivist approach using quantitative methodologies, accounting for $84 \%$ of the reviewed articles (a total of 56 articles). In contrast, we found that both qualitative approaches based on the interpretivist paradigm and mixed methodologies received very little attention from scholars. For instance, $5 \%$ of the publications (three articles) used the qualitative method whereas only $1 \%$ (one article) adopted the mixed method. The remaining seven papers were either literature review or conceptual studies ( $9 \%$ and $1 \%$, respectively). Regarding the type of data used in the literature, our review found that the vast majority of articles commonly used secondary (archival) rather than primary data under quantitative methodology. Also, studies collected secondary data from three primary sources, namely the Microfinance Information Exchange (MIX) Market, www.ratingfund2.org and the financial statements of individual MFIs. Studies mainly considered secondary data since it was readily available on these databases. On the other hand, few studies collected primary data through surveys. Regarding the qualitative method, three studies collected data from MFI boards of directors and senior managers via interviews, while for the mixed method, only one study collected data using heterogeneous techniques, such as interviews, surveys or case studies.

One of the plausible explanations for the use of positivist quantitive research methodologies within corporate governance literature is scholars' use of established literature as examples (Kuhn and Hacking, 2012). In other words, established literature in the field may implicitly or explicitly dictate what methodologies are applied, rather than allowing scholars to develop different epistemological understandings. Alvesson and Sandberg (2011) attributed scholars' fear of pushing the boundaries of an existing paradigm to the scarcity of interesting and influential theories. This is because newcomers in the field may be concerned about upsetting colleagues, reviewers and editors and consequently, the chance of publishing becomes reduced. Thus, we found the majority of peer-reviewed journal publications on microfinance governance research is dominated by positivist paradigms or applied 
quantitative methodologies using large data sets. We also found a small number of studies have used other research methods for data collection, such as case studies and interviews.

These methods allow us to understand the complex organisational and cognitive characteristics of individuals, rather than establish mathematical relationships between corporate governance mechanisms and accounting estimates (Brown and Brignall, 2007). For example, Mori and Charles (2018) and Allemand et al. (2013) conducted their qualitative studies from an interpretivist stance to examine the role of MFI boards in areas such as monitoring management, mobilising resources, creating an institutional network and guiding strategies to improve organisational performance. These authors felt various roles played by MFI boards could be investigated by conducting interviews or qualitative rather than quantitative research. Similarly, Siwale and Okoye (2017) conducted qualitative research on the impact of microfinance regulations in Nigeria and Zambia. The interview evidence taken from various MFI stakeholders suggests that regulations enhance the commercialisation aspect of MFIs by undermining their social mission.

The other concern we have with quantitative approaches is their focus on the validity of their research methods, rather than the reliability of the data. Corporate governance regulations can influence the availability and relevance of information but not necessarily its reliability. Reliability is concerned with the ability of professionals, or other qualified persons, to obtain the same type of data and reach the same conclusions, whereas validity relates to whether a statement, analysis, model, set of concepts or even a discourse expresses, or corresponds to a reality (Nørreklit et al., 2006). Thus, validity applies to the basic structure of concepts and arguments. From the risk reporting perspective, even if quantitative data is proven reliable (i.e. it adheres to common procedures), without a validity assessment, it may be compromised and actions based on it may fail. On the other hand, if the data is valid (i.e. able to provide an adequate idea or picture of the reality, where for example, risk was assessed correctly) but is not reliable, it is considered less problematic since activities based on it will not necessarily fail.

MFI governance literature focused on emerging or developing economies where there are lower institutional transparency requirements, less effective regulations for protecting minority shareholders and a poorer competitive environment, resulting from a lack of anti-trust and anti-monopoly legislation (Johnson et al., 2000; Singh, 2003). Existing research findings could already be biased if reported data was accepted without its reliability being questioned. Win and Kofinas (2019) previously underscored the need for researchers to take into account the potential manipulation of reported data by financial institutions in emerging or developing economies, especially in governance research. Our critique of the dominant paradigms in corporate governance research is not an attempt to discredit these authors. We contend that scholars in governance research should push boundaries set by existing literature and develop new theories and understanding of MFI governance. 


\section{Methodological Application in MFI Governance Research}

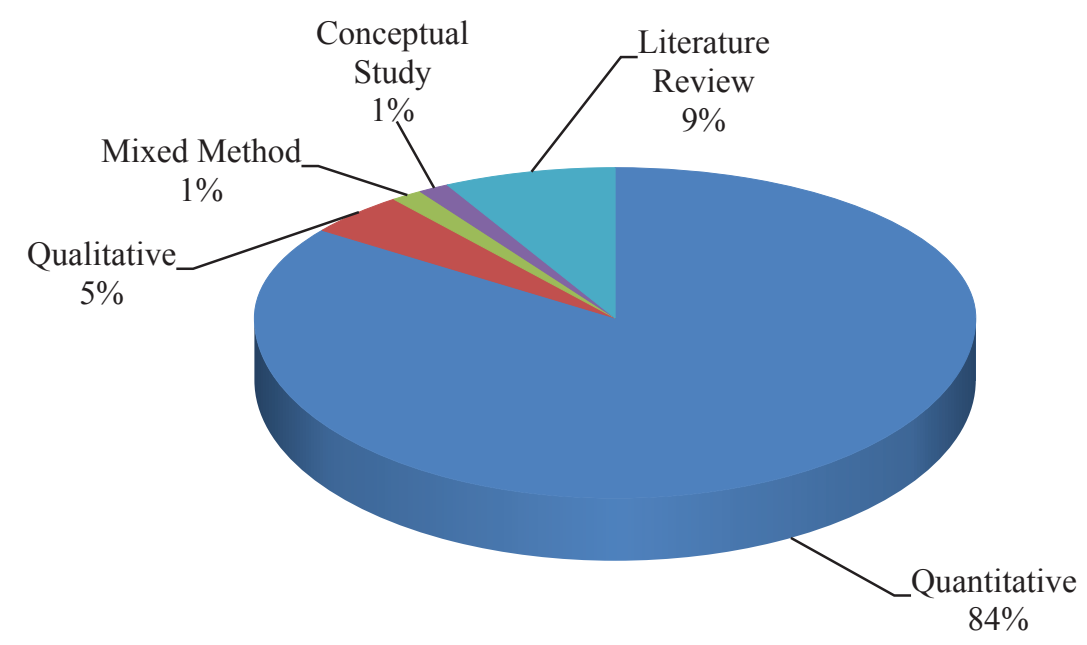

Figure 4. Percentage of Sampled Studies Applying Different Methodologies

\subsection{Geographical Distribution of MFI Governance Studies}

Regarding the study location, we identified the geographical settings where microfinance governance research has taken place, which we presented in the following table. Our endeavour found that the majority of reviewed articles, especially the empirical ones, have investigated governance activities primarily in developing economies. By contrast, only one study with a single country analysis was conducted in a developed country (France). We also found that a wider section of microfinance governance research was carried out with MFIs from multiple countries (34 articles in total). Single country design, on the other hand, accounted for 19 articles but the dual country analysis remains the least commonly sampled context, showing only three articles respectively. The remaining 12 articles did not explicitly mention the geographical coverage.

Table IV. Geographical Distribution of the Selected Articles

\begin{tabular}{|l|l|l|}
\hline Country Sample Design & Geographical Distribution & Total Articles \\
\hline Single-Country Design & Bangladesh (2), India (1), Sri Lanka (3), Pakistan (1), & 19 \\
& Ghana (3), Uganda (2), Ethiopia (2), France (1), \\
Cameroon (1), Nigeria (2), Tanzania (1) & \\
\hline Dual-Country Design & Sri Lanka-India (2), Zambia-Nigeria (1) & 3 \\
\hline Multi-Country Design & 73 countries, 82 countries, 31 countries, 60 countries, & 34 \\
& 73 countries, 54 countries, 73 countries, 67 countries, & \\
& 3 countries, 64 countries, 73 countries, 57 countries, & \\
& 30 countries, 75 countries, 30 countries, 18 countries, & \\
& 73 countries, 35 countries, 41 countries, 76 countries, & \\
& 21 countries, 5 countries, 62 countries, 3 countries, & \\
& 18 countries, 60 countries, 18 countries, 73 countries, & \\
& 60 countries, 6 countries, 34 countries, 76 countries, & \\
& 98 countries, 69 countries & 12 \\
\hline N/A & & \\
\hline
\end{tabular}




\subsection{Theoretical Lenses Applied}

To advance our understanding of theoretical application in existing microfinance governance research, we synthesised several theories, which prior studies applied to explain various CG mechanisms. The findings of our study show that the majority of studies (26 out of 68) were without theoretical direction. Our endeavour found that around 16 of the 42 reviewed articles with theories applied the agency theoretical lens only and related it to different sets of CG actors. Grounded on agency theoretical underpinning, studies mainly looked into the conflicting interests of two diverse groups, commonly known as principals (owners) and agents (managers) (Hartarska, 2005; KyereboahColeman and Osei, 2008; Tchakoute-Tchuigoua, 2010; Thrikawala et al., 2016a; Wamba et al., 2018) to mention a few. These studies, motivated by agency theory framing, have provided us with a rich insight into board monitoring and control of MFI managers (agents). From the perspective of agency theory, managerial engagement in activities, leading to their self-fulfilment goals, damages the interests of investors, shareholders and the long-term survival of firms (Aguilera et al., 2015). Hence, our reviewed articles mostly prioritise the monitoring role of the MFI corporate board.

While many MFI governance studies considered single agency theoretical framing for their empirical analysis, some indeed challenged these boundaries and relied on other theoretical perspectives. As highlighted in Table V, we found that around 25 of 68 sampled articles applied a few or all major corporate governance theories, depending on the type and nature of variables used. For instance, agency theory and resource dependency theory (Van Damme et al., 2016; Iqbal et al., 2019; Mersland et al., 2011; Mori et al., 2013, 2015); agency theory and stakeholder theory (Estapé-Dubreuil and Torreguitart-Mirada, 2015; Hasan et al., 2018; Mersland, 2011; Mori and Mersland, 2014; Nawaz et al., 2018); agency theory, resource dependency theory and stakeholder theory (Quayes and Hasan, 2014); agency theory and institutional theory (Augustine, 2012); agency theory and stewardship theory (Mori and Charles, 2018) and institutional theory, resource dependency theory, agency theory, stewardship theory, stakeholder theory and legitimacy theory (Chakrabarty and Bass, 2014; Djan and Mersland, 2017; Nalukenge et al., 2017; Thrikawala et al., 2017). These studies developed our understanding that multiple governance theories would better explain the diverse functions of MFI boards as well as the requirements of stakeholders in the firm.

On the other hand, a very small number of articles (four articles) departed from key governance theories and applied different theories to study MFI governance, such as ownership theory (Mersland and Strøm, 2008); critical mass theory (Strøm et al., 2014); motivated agent theory (Randøy et al., 2013) and gender role theory (Augustine et al., 2016). Under the presumptions of this group of theories, authors separately explored some specific governance attributes (e.g. ownership type, gender diversity and entrepreneur CEOs) and their association with MFI performance. Three other studies used pecking order theory, trade-off theory and agency theory to investigate governance and MFI debt capital structure (Adusei and Obeng, 2019; Kyereboah-Coleman, 2007a; Ndaki et al., 2018).

\subsection{Key Dimensions of Governance Addressed}

Our results revealed that the majority of studies (41 articles) focused primarily on both internal and external governance mechanisms and investigated their combined effect on a variety of commonly used MFI performance-related indicators (see Table V). Out of the total sample, very few studies (five articles) focused on external governance mechanisms, for example, MFI regulation, rating and external audit (Hartarska, 2009); external audit (Beisland et al., 2018); rating disclosure (Quayes and Hasan, 2014); rating agencies (Hartarska and Nadolnyak, 2008) and MFI regulation, external audit, competition, rating and six dimensions of country-level governance (Nihel and Younes, 2015). 
Given that internal and external governance mechanisms have been a central focus of many studies in shaping the governance structure, undoubtedly, the board of directors and leadership characteristics within MFIs have caught the attention of past scholars. We found that one set of articles intensively researched some of the common attributes of internal governance structure, for example, board size, board independence, gender diversity, the internal auditor, ownership type, board committees, CEOchairman duality and leverage (Abate et al., 2014; Augustine et al., 2016; Dato et al., 2018; Mersland and Strøm, 2008; Mori et al., 2015; Servin et al., 2012). While board education, board meeting frequency and CEO tenure are three important components of internal governance, their presence in the literature is rare and we found only one study that focused on these components (KyereboahColeman and Osei, 2008). Nevertheless, studies using internal governance mechanisms strongly emphasised the internal monitoring and management control of MFI boards.

\subsection{Antecedents and Consequences of Governance}

We searched extensively through all selected articles to identify antecedents or factors that determine microfinance governance. Surprisingly, we found that research on the determinants of MFI governance is rather sparse and, to a large extent, remains undiscovered. However, a few recent empirical works in this setting have examined the interconnection between several institutional, individual or firm-level governance characteristics and the dynamic relationship between corporate boards and MFI performance.

For instance, in their study, Mori et al. (2013) investigated the individual and firm-level determinants of the MFI corporate board. Their study revealed that some corporate governance characteristics play a significant role in shaping the board structure of an MFI. These characteristics include international influence, regulation and founder management. In a similar vein, Mori and Mersland (2014) conducted another study to determine whether or not stakeholders (donors, creditors, employees and customers) influence MFI governance and performance. Their study demonstrated that the presence of stakeholders varies among different ownership types of MFI and boards are constituted differently. For example, NGOs hire more donors and employees while cooperatives and banks hire more customers and creditors in their boardroom. Also, donor representation is related to smaller board size, CEO non-duality and better firm performance; employee representation is connected with larger board size while customer and creditor representation is related to CEO duality and financial performance. More recently, Djan and Mersland (2017) studied the link between religious affiliation and MFI corporate governance structure. Their study findings suggest that religious affiliation indeed shapes MFI governance structure with respect to audit quality, board meeting frequency and the hiring of foreign directors.

Regarding the dynamic nature of governance and MFI performance relationship, Mori and Mersland (2014) dealt with the possibility of endogeneity concerns using a data analysis technique called twostage least squares (2SLS) regression. They claimed that both stakeholder representation and MFI performance are endogenously determined. Further, Quayes and Hasan (2014) applied a three-stage least squares technique to delineate a possible endogenous relationship between explanatory and dependent variables. They found MFI rating disclosure and financial performance positively influence each other simultaneously. This assertion is strongly supported by the more recent empirical works of Thrikawala et al. (2016b, 2017). These authors applied a more advanced and dynamic panel data estimation technique known as the Generalised Method of Moments (GMM) to account for endogeneity arising from various sources. Their findings suggest that the past performance of MFIs significantly determines their contemporaneous governance structure. That is, past performance and governance of MFIs hold a bidirectional relationship. 
Other studies used an external governance mechanisms called MFI rating, as a measurement indicator for microfinance governance quality and connected it to a set of governance attributes. For example, Beisland et al. (2014) found that governance mechanisms such as CEO duality, foreign directors, internal audit and competition significantly influence the rating performance of MFIs. In a similar vein, Tchakoute-Tchuigoua (2015) investigated the determinants of microfinance governance quality. His study found that key CG mechanisms such as board committee, board expertise, board activity and ownership type are influencing factors for MFI rating scores as a proxy of governance quality. Further, Beisland et al. (2015) made efforts to examine the relationship between audit quality and MFI governance. Using two proxies for audit quality (namely, internal auditor presence and big-4 external auditor presence), they found that board structure and other corporate governance variables are key determinants of audit quality. Overall, we found that surprisingly few studies addressed the antecedents of MFI governance, which may be because research in this discipline is emerging.

For governance and the MFI performance relationship, there exists a plethora of studies in the literature. We found the majority of studies with diverse theories and methodological techniques have addressed this relationship in a variety of geographical contexts. We briefly discuss this relationship here.

The performance of MFIs, as identified from selected studies, is twofold: financial and social, commonly known as the 'MFI dual bottom line'. Also, scholars have measured these two performance dimensions using a range of accounting measurement indicators. These indicators together for both performance variables include return on asset (ROA), return on equity (ROE), operational self-sufficiency (OSS), financial self-sufficiency (FSS), portfolio at risk>30days (PAR), operational expenses (OpEx), depth of outreach-average loan balance per borrowers/GNI per capita (ALB) and breadth of outreach, number of active borrowers (NAB) and number of women borrowers (NWB). Our extensive literature review found the majority of empirical articles searched for the impact of corporate governance on both financial and social performance. Conversely, seven articles estimated the influence of governance on the social and financial performance of MFIs separately (see Table V).

As highlighted in Table $\mathrm{V}$, most prior studies conclude there is a strong correlation between governance and performance of MFIs. However, empirical evidence of this relationship is incongruent. For instance, some studies found that governance structure positively influences the performance of MFIs (Allemand et al., 2013; Augustine, 2012; Augustine et al., 2016; Chakrabarty and Bass, 2014; Dato et al., 2018; Kyereboah-Coleman and Osei, 2008; Mori et al., 2015; Nihel and Younes, 2015; Pascal et al., 2017; Strøm et al., 2014; Tchakoute-Tchuigoua, 2010; Thrikawala et al., 2016a, 2017; Wamba et al., 2018) to mention few. Other studies found that governance structure both positively and negatively affects MFI performance (Abate et al., 2014; Bakker et al., 2014; Bassem, 2009; Van Damme et al., 2016; Estapé-Dubreuil and Torreguitart-Mirada, 2015; Gohar and Batool, 2015; Hartarska, 2005; Hartarska and Mersland, 2012; Mersland and Strøm, 2009). In contrast, some studies did not find any correlation between governance and MFI performance variables (Aboagye and Otieku, 2010; Hartarska, 2009; Mersland and Strøm, 2008; Siwale and Okoye, 2017). We assume this departure from past findings may have resulted from differences in data and data analysis tools.

\section{Discussion, Literature Gaps and Future Research Directions}

In this section, to address our second review question $(R Q 2)$, we highlight some research gaps in the prevailing MFI governance literature and open up some heterogeneous roadmaps for future research. 
We anticipate that many researchers will be interested in undertaking future work in the suggested areas of microfinance governance. We present them as follows:

\subsection{Future Empirical Directions}

First, a large number of reviewed studies have investigated the causal relationship between CG mechanisms and MFI performance. Until now, these studies have measured MFI performance according to financial and social dimensions. However, rapidly transforming global MFIs are now considering various dimensions together for their performance (Allet and Hudon, 2015). One performance dimension that has not yet been linked empirically to the governance and performance research is MFI environmental performance, also known as the 'third bottom line'. Scholars suggest, among other things, that human resource management and governance issues of MFIs could also influence their environmental performance (Forcella and Hudon, 2016). That is, the managerial exercise of corporate social responsibility (CSR) practice and MFIs' engagement could influence their commitment to society. Although García-Pérez et al. (2018) and Tanin et al. (2019) have recently attempted to touch on this subject, they have not fully investigated the impact of different sets of corporate governance mechanisms on all three performance dimensions of MFIs. Therefore, which governance structures can effectively influence the social business behaviour of organisations is an ongoing debate (Walls et al., 2012) and this deserves further empirical inquiry (García-Perez et al., 2017).

Second, ownership type is one of the important governance mechanisms of MFIs. However, a limited number of past empirical studies have investigated the influence of different ownership types on MFI performance (see Table V). Scholars have classified MFI ownership into nonprofit and for-profit categories. Accordingly, existing studies have mostly classed NGOs and cooperatives together as non-profit ownership, while banks and NBFIs as for-profit ownership. Although all MFIs have the same financial and social motives, their relative weights vary across organisational types (Servin et al., 2012). For example, banks, cooperatives and NBFIs are different from NGOs as they distribute profits to their stakeholders. Unlike NGOs, cooperatives are member-based institutions that follow the 'one person one vote' principle, irrespective of how much they invest in the cooperatives (Barry and Tacneng, 2014; Mia, 2016). Further, unlike banks, the scope of NBFIs in providing financial services is legally limited (i.e., some cannot offer savings accounts) despite the fact that they are shareholding institutions (Servin $\boldsymbol{e t}$ al., 2012). Unlike banks and NBFIs, board members of non-profit MFIs rarely have a financial stake in the institution and often lack financial expertise in managing risk, which may perhaps decrease the board monitoring of managers. Some state-owned MFIs actively involved in microfinance programmes also differ from private MFIs in that they are highly regulated and their ownership is claimed by the government.

These distinctions between MFIs indicate that it is more appropriate to look at different MFI ownership types separately, rather than examine them jointly, in order to capture their individual effect on MFI performance. Further, MFI ownership types may influence the formation of board structures in terms of the size of boards, CEO characteristics and the presence of stakeholders in the boardroom. Similarly, Islamic MFIs also differ from conventional MFIs in terms of their governance system since they have Shariah supervisory boards and remain compliant with Shariah laws, while providing financial services to the poor. In this case, the governance environment to mitigate agency problems and discipline management may vary across financial providers. Future studies can address these issues and add increased understanding to MFI governance literature. 
Third, the findings of empirical studies have provided us with insight into the MFI board and performance nexus but it turns out that studies have mainly focused on a direct relationship. We suggest future research could dwell on an indirect relationship and examine the contingency effects, devoting sufficient attention to a mediating role in terms of what is happening behind the scenes in MFI boardrooms. For this, future authors may build their work on board process by addressing three key factors, namely board mutual trust, the conflict between board members and conflict management practices (Mori et al., 2015). Such work will not only become a magnum opus providing us with a broader depiction of this relationship but also contribute new knowledge to the field's governance literature, both theoretically and empirically.

Fourth, regarding the interplay between external and internal governance characteristics, we point out the need for further research. In our opinion, internal CG mechanisms do not remain in isolation but depend on other external mechanisms. For example, external governance actors such as regulation, competition, external stakeholders and external audit may sometimes interact with the monitoring role of boards and determine board formation. However, our reviewed literature has largely neglected this interaction process. Accordingly, it will be fruitful to examine the interaction between internal and external governance mechanisms (Cuomo et al., 2016; de Haan and Vlahu, 2016) and their capacity to influence the dual institutional logics of MFIs (Nihel and Younes, 2015).

Fifth, the capital structure or funding choice of MFIs, which is regarded as an internal governance mechanism (Filatotchev and Wright, 2017), can be a promising area for future research. Indeed, some of our reviewed articles used the capital structure as a control covariate, proxied by leverage in their regression analysis. Findings of these studies demonstrated a significant influence of leverage on MFI performance. Scholars assert that MFIs need diversified sources of capital for funding their operations (Kyereboah-Coleman, 2007b; Tchakoute-Tchuigoua et al., 2017) and their governance structure is crucial to ensure that capital provided by investors is used to serve their intended purposes (Hartarska, 2005). Yet, the existing literature has largely overlooked the connection between governance and MFI capital structure. Although some scholars attempted to address this topic using a few governance mechanisms, the focus was mainly on MFI debt capital and, to a small extent, equity structure (Adusei and Obeng, 2019; Beisland et al., 2018; Hartarska and Nadolnyak, 2008; Kyereboah-Coleman, 2007a; Ndaki et al., 2018). We suggest future scholars consider other sources of capital, such as donations and public deposits. This is particularly important since many MFIs, in particular the non-profit and deposit-taking institutions, rely much on donations and deposits for business operations. Profit motivated MFIs seek equity finance from shareholders too. Therefore, sectoral governance may play a critical role in raising funds from varied sources and this requires future investigation.

Sixth, regarding governance disclosure quality, more empirical research is needed. Our review found that only a handful of studies investigated the determinants of MFI governance quality. It is also evident that past studies used a limited number of governance mechanisms (Beisland et al., 2014; Tchakoute Tchuigoua, 2015). Future scholars can extend the current line of inquiry by drawing on a longitudinal analysis with improved measurements of MFI governance disclosure quality. Future scholars can also examine whether or not any link exists between disclosure quality and MFI cost of debt or equity capital.

Seventh and finally, gender diversity in MFI boardrooms has become a central interest for debate by past scholars. A large pool of reviewed articles suggests that microfinance governance scholars have mainly explored the association between female directors and the organisational performance of MFIs. However, past scholars often neglected to address some personal characteristics of female directors such as age, educational level and marital status, which can be an interesting topic for future 
research in this field. Future scholars need to go beyond the consequences of MFI gender diversity and examine what determines this diversity empirically, focussing specifically on two hierarchical levels, namely, board level and management level.

\subsection{Future Theoretical Directions}

In terms of theory, various issues that we highlighted in the findings must be addressed by future research. We believe that new and other existing management theories could lead future research in the right direction and address many complex issues of microfinance governance. In this regard, we offer some theoretical suggestions.

From our findings, we noticed that mainstream literature over-relied on a single agency theoretical lens, paying near exclusive attention to the board oversight role. However, there is growing agreement that boards can play many other critical roles in the firm which, literature in our review either only touched upon slightly or, to a large extent, ignored. Studies that apply various theories underpinning microfinance governance outcomes are few and far between. Hence, our understanding of theoretical applications in the field's governance literature is currently incomplete. In our view, the new empirical research directions proposed earlier can be explored in the future from a multi-theoretical standpoint. A multi-theoretic approach that incorporates a group of governance theories can bridge some of the gaps in agency theory and help recognise key dimensions of good governance within one framework (Christopher, 2010).

MFIs are more likely to be stakeholder-oriented since the majority of them are not-for-profit organisations. Hence, different types of stakeholders (such as customers, creditors, donors, shareholders, government agencies and employees) are actively involved in MFI boards (Mori, 2010; Mori and Mersland, 2014). Their presence in boards with diverse interests can have different influences on the firm's strategic decisions and performance outcomes, depending on the nature and type of ownership. In sum, stakeholders are defined as those groups or individuals that may influence or be influenced by organisational objectives and actions (Freeman, 1984). Our reviewed literature has largely ignored this view and taken the narrow agency theoretical approach, thus failing to address MFI governance from a stakeholder perspective. Taking the stakeholder theoretic framing into consideration, future researchers could, for instance, benefit from probing how multiple entities sitting in the MFI boardroom potentially impact varied institutional outcomes. Additionally, future researchers could investigate whether or not these stakeholders have any influence on the demand side of microfinance (e.g. MFI borrowers) by considering corporate social responsibility (CSR) practices.

Resource allocation is an important strategic decision made by MFI boards for organisational survival. This strategy is crucial for microfinance operations as it provides better synergies and, by reallocating resources, adjusts the gap between the financial and social objectives of MFIs (Mia et al., 2016). However, this issue has largely been ignored by the research papers reviewed in this study. It may be because studies in this field have looked at governance issues from a management perspective and not from an economic one. This is rather unfortunate, as microfinance is an integral part of the economy. Hence, we suggest future scholars consider the efficient resource allocation theory when studying microfinance governance.

Future scholars can also draw on a new theoretical lens to study MFIs governance, for example, the behavioural theory of corporate governance. The behavioural theory posits that firms comprise distinct coalitions of groups with diverse preferences that may potentially lead to conflicts of interests between the groups (Cyert and March 1963). In this case, boards, as corporate governance institutions, can resolve these conflicts through negotiation between various coalitions and by 
establishing controls, so that firms aiming to achieve goals reflect the preferences of the dominant coalition (Desai, 2016; Van Ees et al., 2009; Elghuweel et al., 2017). To our knowledge and based on the study findings, no research has yet been conducted that examines MFI corporate boards and governance grounding in this theory and as such, this warrants future investigation.

\subsection{Future Methodological Directions}

In this section, we highlight some methodological issues that emerged from the reviewed literature and, in light of these issues, provide future scholars with some room for further development. As illustrated, a common methodological application noticed from the reviewed literature is quantitative methodology, particularly as prior scholars have been motivated by a theory testing approach. Even though quantitative methodology is prevalent in the literature, it is not devoid of limitations that must be addressed by future research. For instance, a significant number of empirical works relied heavily on archival data that were hand-collected from available sources. The archival dataset may be biased towards MFIs that participate in the databases on a voluntary basis and these may be particularly in need of disclosure to donors and international investors (Barry and Tacneng, 2014).

It is further argued that the Mix Market obtains data from most MFIs, which are already efficient in their operations, paying close attention to profitability and portfolio quality (Gonzalez, 2007). This triggers concerns about whether or not socially motivated MFIs are present in the samples derived from such databases (Mia et al., 2018). In addition, many governance variables-related data are not readily available in the Mix Market. Similarly, rating agencies, which perhaps provide better quality data, do not always possess data for all time periods and for all MFIs (Hartarska and Nadolnyak, 2008; Lensink et al., 2018). These limitations lead to concerns about the sampling representativeness of many empirical studies considered for review. We suggest future scholars collect data in the form of a quantitative scale using alternative methods, such as surveys with MFI board members. This approach will enable researchers to obtain fresh, real-time data from individual MFIs, often not accessible through historical datasets.

Many empirical studies collected data from only rated MFIs. Hence, the findings of these studies do not represent non-rated institutions. Including non-rated MFIs to the sample can generalise the overall results of a study. Therefore, future scholars need to consider both rated and non-rated MFIs for their sample. Further, as shown in the findings section, the vast majority of empirical studies on governance and MFI performance relationship used various statistical tools for panel data analysis. Arguably, these tools are not strong enough to control for the endogeneity that arises from three potential sources, namely: unobserved heterogeneity, reverse causality and dynamic endogeneity (Schultz et al., 2010; Wintoki et al., 2012). Corporate governance variables are endogenously determined by different firm-level characteristics and institutional outcomes: strategies, innovation and performance (Filatotchev and Wright, 2017). To account for endogeneity problems in MFI governance research, we encourage future scholars to apply more powerful and advanced data estimation tools, such as different lag structures of variables, GMM and the like.

By contrast, qualitative methodology with theory building approaches received relatively little attention from past scholars. Hence, we call for more qualitative studies that nurture the current body of literature and contribute meaningfully to the advancement of sectoral governance research. We think the time has now come to research MFI governance issues in a qualitative way. Qualitative studies on microfinance governance will help us gain a deeper understanding of MFI boardroom behaviour. Studying boardroom interaction is especially pivotal to understanding how boards of MFIs work, as they are usually composed of diverse stakeholder representatives (including clients, donors, employees and investors) (Mori and Mersland, 2014). Conflicts may arise from different stakeholders 
on boards with a diverse range of interests, which may result in contrasting opinions on board decision-making (Hermes, 2019). It is crucial for MFI boards to negotiate with members representing different stakeholder interests, in order to best manage conflicts. How MFI boards manage conflicts is an interesting research topic, which can be explored through a qualitative approach. To do so, potential researchers can conduct in-depth interviews and/or observations with MFI board members on board process, roles and responsibilities. Future scholars can also collect directors' views and perceptions as to how decisions are made to achieve different institutional goals. Future scholars could also combine interviews with regression analysis (qualitative and quantitative methodologies). The advantage of using both methodologies is that studies could contain extra granularity in their findings and one methodology may also perhaps confirm the results of the other and vice versa (Evanschitzky and Goergen, 2018).

\subsection{Future Geographical Directions}

In terms of geographical context, the majority of studies in our review used data from MFIs in multiple countries. Empirical studies mostly and repeatedly collected data from MFIs located in different geographical areas, such as Latin America, Africa and Europe (see Table V). We found few studies taking place in the Asian region and more specifically, south Asian countries. Those that did addressed the governance and performance relationship only. We encourage future scholars to consider these countries for topics such as governance and capital structure (i.e. donation and equity capital), MFI triple bottom line, disclosure practices and audit quality.

Further, multi-country sampling design is good for greater comparability and generalisability of obtained results but, in our opinion, future research should not frequently collect data from the same regions but rather, focus strongly on underexplored areas that may lead to the expansion of geographical coverage. We advocate future researchers base their empirical analysis on a crosscountry comparison, especially between developed and developing economies. Such research will facilitate greater understanding of cross-country differences and shed more light on theoretical advancement. Future studies could also concentrate on small country analysis in a specific geographic region with a strong justification as to why countries from a given region are investigated and what driving factors influence the selection of these countries (Boyd et al., 2017).

\section{Conclusions and Recommendations}

After an extensively critical evaluation of quality governance studies in microfinance territory, we have reached our conclusion that, all else being equal, governance structure is the sine qua non of microfinance institutions. Our literature review finds that existing studies have addressed multifaceted issues of MFI governance. It reveals that a burgeoning research interest lies in governance and institutional performance of MFIs, even though a few studies have highlighted the determinants of governance and, to some extent, MFIs audit and disclosure practices. Further, the study finds that research on microfinance governance has surged in recent times, which may be due to the fact that the sector has developed from a nascent to a relatively mature stage, indicating that governance can play a critical role in such advancement. In addition to some scholarly contributions to the field, the results of our study unveil multiple gaps in current MFI governance literature and provide directions for further consideration. Our comprehensive literature review encourages microfinance governance scholars to examine numerous issues in order to reach a mature understanding of the phenomenon and take microfinance governance research a further step forward. 


\subsection{Limitations}

As with many review papers, we acknowledge several shortcomings of our work. First, in line with our study inclusion and exclusion criteria, we incorporated only quality peer-reviewed academic journals in our study and left out some potentially relevant publications. Future reviews may look into this issue and include more possible publications. Second, we did not solely review studies on MFI governance and performance relationship, but, during our review process, noted that many studies presented their paradoxical findings apropos of this relationship. We suggest meta-analysis could be conducted on this topic for better clarity as to the overall performance effects of different governance mechanisms. Third, due to a lack of language skills on our part and item access limit, our literature search omitted some publications in non-English languages. Fourth and finally, our keyword searches were restricted to only seven databases of choice which, albeit sensibly comprehensive, indicates we may have missed some articles available on other databases. Future reviews can include more databases in order to cover a wider range of relevant materials.

In spite of the limitations we highlighted above, our rigorous literature review approach compiled a variety of scholarly articles for review, building a strong foundation of literature that well represents quality and influential contributions to the field's governance research. To this end, we hope the omission of some articles is less likely to alter the conclusion of our study. We believe our study serves as a starting point for a profound understanding of the current state of MFI governance.

\section{References}

Abate, G.T., Borzaga, C. and Getnet, K. (2014), "Cost-efficiency and outreach of microfinance institutions: trade-offs and the role of ownership", Journal of International Development, Vol. 26 No. 6, pp. 923-932.

Aboagye, A.Q. and Otieku, J. (2010), “Are Ghanaian MFIs' performance associated with corporate governance?", Corporate Governance: The International Journal of Business in Society, Vol. 10 No. 3, pp. 307-320.

Adams, A. and Tewari, D.D. (2017), "Determinants of microfinance outreach in Sub-Saharan Africa: a panel approach", Acta Commercii, Vol. 17 No. 1, pp. 1-10.

Adusei, M. and Obeng, E.Y.T. (2019), "Board gender diversity and the capital structure of microfinance institutions: A global analysis", Quarterly Review of Economics and Finance, Vol. 71, pp. 258-269.

Aguilera, R. V., Desender, K., Bednar, M.K. and Lee, J.H. (2015), "Connecting the dots: bringing external corporate governance into the corporate governance puzzle", Academy of Management Annals, Vol. 9 No. 1, pp. 483-573.

Ahmad, S. and Omar, R. (2016), "Basic corporate governance models: a systematic review", International Journal of Law and Management, Vol. 58 No. 1, pp. 73-107.

Ahmed, K. and Khan, R. (2016), "Disclosure practices and governance quality: evidence from micro finance institutions", Journal of Accounting \& Organizational Change, Vol. 12 No. 3, pp. 325350 .

Albliwi, S.A., Antony, J. and Lim, S.A.H. (2015), "A systematic review of Lean Six Sigma for the manufacturing industry", Business Process Management Journal, Vol. 21 No. 3, pp. 665-691.

Allemand, I., Brullebaut, B. and Raimbault, S. (2013), "Exploring the role of the board of directors in cooperatives: lessons for microfinance", Strategic Change, Vol. 22 No. 1-2, pp. 79-93. 
Allet, M. (2014), "Why do microfinance institutions go green? an exploratory study", Journal of Business Ethics, Vol. 122 No. 3, pp. 405-424.

Allet, M. and Hudon, M. (2015), "Green microfinance: characteristics of microfinance institutions involved in environmental management", Journal of Business Ethics, Vol. 126 No. 3, pp. 395414.

Alvesson, M. and Sandberg, J. (2011), "Generating research questions through problematization", Academy of Management Review, Vol. 36 No. 2, pp. 247-271.

Augustine, D. (2012), "Good practice in corporate governance: transparency, trust, and performance in the microfinance industry”, Business \& Society, Vol. 51 No. 4, pp. 659-676.

Augustine, D., Baraldi, M., Wheat, C.O., Malgwi, C.A. and Jones, K.S. (2016), "Gender diversity within the workforce in the microfinance industry in Africa: economic performance and sustainability", Canadian Journal of Administrative Sciences, Vol. 33 No. 3, pp. 227-241.

Bakker, A., Schaveling, J. and Nijhof, A. (2014), "Governance and microfinance institutions", Corporate Governance: The International Journal of Business in Society, Vol. 14 No. 5, pp. 637-652.

Barr, A., Fafchamps, M. and Owens, T. (2005), "The governance of non-governmental organizations in Uganda", World Development, Vol. 33 No. 4, pp. 657-679.

Barry, T.A. and Tacneng, R. (2014), "The impact of governance and institutional quality on MFI outreach and financial performance in Sub-Saharan Africa", World Development, Vol. 58, pp. $1-20$.

Bassem, B.S. (2009), "Governance and performance of microfinance institutions in Mediterranean countries", Journal of Business Economics and Management, Vol. 10 No. 1, pp. 31-43.

Battilana, J. and Dorado, S. (2010), "Building sustainable hybrid organizations: the case of commercial microfinance organizations", Academy of Management Journal, Vol. 53 No. 6, pp. $1419-1440$.

Becheikh, N., Landry, R. and Amara, N. (2006), "Lessons from innovation empirical studies in the manufacturing sector: a systematic review of the literature from 1993-2003", Technovation, Vol. 26 No. 5-6, pp. 644-664.

Beisland, L.A., Mersland, R. and Øystein, R. (2015), "Audit quality and corporate governance: evidence from the microfinance industry.", International Journal of Auditing, Vol. 19 No. 3, pp. $218-237$.

Beisland, L.A., Mersland, R. and Randøy, T. (2014), "The association between microfinance rating scores and corporate governance: a global survey", International Review of Financial Analysis, Vol. 35, pp. 268-280.

Beisland, L.A., Mersland, R. and Strøm, Ø. (2018), "Use of Big Four auditors and fund raising: evidence from developing and emerging markets", International Journal of Emerging Markets, Vol. 13 No. 2, pp. 330-349.

Bibi, U., Balli, H.O., Matthews, C.D. and Tripe, D.W.L. (2018), "Impact of gender and governance on microfinance efficiency", Journal of International Financial Markets, Institutions and Money, Vol. 53, pp. 307-319.

Boubacar, H. (2018), "Internal governance mechanisms and the performance of decentralized financial systems in Niger", International Journal of Social Economics, Vol. 45 No. 4, pp. 629643. 
Boyd, B.K., Gove, S. and Solarino, A.M. (2017), "Methodological rigor of corporate governance studies: a review and recommendations for future studies", Corporate Governance: An International Review, Vol. 25 No. 6, pp. 384-396.

Brown, R. and Brignall, S. (2007), "Reflections on the use of a dual-methodology research design to evaluate accounting and management practice in UK university central administrative services", Management Accounting Research, Vol. 18 No. 1, pp. 32-48.

Chakrabarty, S. and Bass, A.E. (2014), "Corporate governance in microfinance institutions: board composition and the ability to face institutional voids", Corporate Governance: An International Review, Vol. 22 No. 5, pp. 367-386.

Chiu, T. (2015), "Factors influencing microfinance engagements by formal financial institutions", Journal of Business Ethics, Vol. 143 No. 3, pp. 565-587.

Christofi, M., Leonidou, E. and Vrontis, D. (2017), "Marketing research on mergers and acquisitions: a systematic review and future directions", International Marketing Review, Vol. 34 No. 5, pp. 629-651.

Christopher, J. (2010), "Corporate governance: a multi-theoretical approach to recognizing the wider influencing forces impacting on organizations", Critical Perspectives on Accounting, Vol. 21 No. 8, pp. 683-695.

Crossan, M.M. and Apaydin, M. (2010), "A multi-dimensional framework of organizational innovation: a systematic review of the literature", Journal of Management Studies, Vol. 47 No. 6, pp. 1154-1191.

Cuomo, F., Mallin, C. and Zattoni, A. (2016), "Corporate governance codes: a review and research agenda”, Corporate Governance: An International Review, Vol. 24 No. 3, pp. 222-241.

Cyert, R.M. and March, J.G. (1963), A Behavioral Theory of the Firm, Prentice-Hall, Englewood Cliffs, NJ.

Van Damme, P., Wijesiri, M. and Meoli, M. (2016), "Governance and efficiency of microfinance institutions: empirical evidence from Sri Lanka", South Asia Economic Journal, Vol. 17 No. 2, pp. 1-12.

Dato, H.M., Mersland, R. and Mori, N. (2018), "Board committees and performance in microfinance institutions: evidence from Ethiopia”, International Journal of Emerging Markets, Vol. 13 No. 2, pp. 350-370.

Desai, V.M. (2016), "The behavioral theory of the (governed) firm: corporate board influences on organizations' responses to performance shortfalls", Academy of Management Journal, Vol. 59 No. 3, pp. 860-879.

Djan, K.O. and Mersland, R. (2017), "Does religious affiliation influence the design of corporate governance? evidence from the global microfinance industry", Strategic Change, Vol. 26 No. 2, pp. 101-116.

Van Ees, H., Gabrielsson, J. and Huse, M. (2009), "Toward a behavioral theory of boards and corporate governance", Corporate Governance: An International Review, Vol. 17 No. 3, pp. $307-319$.

Elghuweel, M.I., Ntim, C.G., Opong, K.K. and Avison, L. (2017), "Corporate governance, Islamic governance and earnings management in Oman", Journal of Accounting in Emerging Economies, Vol. 7 No. 2, pp. 190-224.

Estapé-Dubreuil, G. and Torreguitart-Mirada, C. (2015), "Governance mechanisms, social 
performance disclosure and performance in microfinance: does legal status matter?", Annals of Public and Cooperative Economics, Vol. 86 No. 1, pp. 137-155.

Evanschitzky, H. and Goergen, M. (2018), "Looking forward, looking back: British Journal of Management 2000-2015”, British Journal of Management, Vol. 29 No. 1, pp. 3-9.

Filatotchev, I. and Wright, M. (2017), "Methodological issues in governance research: An editor's perspective", Corporate Governance: An International Review, Vol. 25 No. 6, pp. 454-460.

Forcella, D. and Hudon, M. (2016), "Green microfinance in Europe”, Journal of Business Ethics, Vol. 135 No. 3, pp. 445-459.

Freeman, R.E. (1984), Strategic Management: A Stakeholder Approach, Pitman, Boston.

Galema, R., Lensink, R. and Mersland, R. (2012a), "Governance and Microfinance Institutions", in Barth, J.R., Lin, C. and Wihlborg, C. (Eds.), Handbook on International Banking and Governance, Edward Elgar Publishing Ltd., Cheltenham, UK, pp. 565-578.

Galema, R., Lensink, R. and Mersland, R. (2012b), "Do Powerful CEOs Determine Microfinance Performance?", Journal of Management Studies, Vol. 49 No. 4, pp. 718-742.

García-Perez, I., Mu, M.-J. and Fernandez-Izquierdo, M.-A. (2017), "Microfinance literature: A sustainability level perspective survey", Journal of Cleaner Production, Vol. 142, pp. 33823395.

García-Pérez, I., Muñoz-Torres, M.J. and Fernández-Izquierdo, M.Á. (2018), "Microfinance institutions fostering sustainable development", Sustainable Development, Vol. 26 No. 6, pp. 606-619.

Gohar, R. and Batool, A. (2015), "Effect of corporate governance on performance of microfinance institutions: a case from Pakistan", Emerging Markets Finance \& Trade, Vol. 51 No. S6, pp. S94-S106.

Gonzalez, A. (2007), Resilience of Microfinance Institutions to National Macroeconomic Events: An Econometric Analysis of MFI Asset Quality, SSRN Electronic Journal, available at:https://doi.org/10.2139/ssrn.1004568.

Guinnane, T.W. (2001), "Cooperatives as information machines: German rural credit cooperatives , 1883-1914”, The Journal of Economic History, Vol. 61 No. 2, pp. 366-389.

Gupta, N. and Mirchandani, A. (2019), "Corporate governance and performance of microfinance institutions: recent global evidences”, Journal of Management \& Governance, pp. 1-20.

de Haan, J. and Vlahu, R. (2016), "Corporate governance of banks: a survey", Journal of Economic Surveys, Vol. 30 No. 2, pp. 228-277.

Habib, A. and Jiang, H. (2015), "Corporate governance and financial reporting quality in China: a survey of recent evidence", Journal of International Accounting, Auditing and Taxation, Vol. 24, pp. 29-45.

Hartarska, V. (2005), "Governance and performance of microfinance institutions in Central and Eastern Europe and the Newly Independent States", World Development, Vol. 33 No. 10, pp. 1627-1643.

Hartarska, V. (2009), "The impact of outside control in microfinance", Managerial Finance, Vol. 35 No. 8, pp. 975-989.

Hartarska, V. and Mersland, R. (2012), "Which governance mechanisms promote efficiency in 
reaching poor clients? evidence from rated microfinance institutions", European Financial Management, Vol. 18 No. 2, pp. 218-239.

Hartarska, V. and Nadolnyak, D. (2008), "Does rating help microfinance institutions raise funds? Cross-country evidence", International Review of Economics \& Finance, Vol. 17 No. 4, pp. $558-571$.

Hasan, T., Quayes, S. and Khalily, B. (2018), "Role of governance on performance of microfinance institutions in Bangladesh", Eurasian Economic Review, Vol. 9 No. 1, pp. 1-16.

Helms, B. (2006), Access for All: Building Inclusive Financial Systems, C-GAP, Washington, DC.

Hermes, N. (2019), "Microfinance and governance", in Hudon, M., Labie, M. and Szafarz, A. (Eds.), A Research Agenda for Financial Inclusion and Microfinance, Edward Elgar Publishing Ltd., Cheltenham, UK, pp. 150-161.

Hermes, N. and Hudon, M. (2018), "Determinants of the performance of microfinance institutions: A systematic review", Journal of Economic Surveys, Vol. 32 No. 5, pp. 1483-1513.

Hermes, N. and Lensink, R. (2007), "The empirics of microfinance: What do we know?", The Economic Journal, Vol. 117 No. 517, pp. F1-F10.

Hollis, A. and Sweetman, A. (2001), "The life-cycle of a microfinance institution: The Irish loan funds", Journal of Economic Behavior and Organization, Vol. 46 No. 3, pp. 291-311.

Hollis, A. and Sweetman, A. (2004), "Microfinance and famine: The Irish loan funds during the Great Famine", World Development, Vol. 32 No. 9, pp. 1509-1523.

Im, J. and Sun, S.L. (2015), "Profits and outreach to the poor: The institutional logics of microfinance institutions", Asia Pacific Journal of Management, Vol. 32 No. 1, pp. 95-117.

Iqbal, S., Nawaz, A. and Ehsan, S. (2019), "Financial performance and corporate governance in microfinance: Evidence from Asia", Journal of Asian Economics, Vol. 60, pp. 1-13.

Johnson, S., Boone, P., Breach, A. and Friedman, E. (2000), "Corporate governance in the Asian financial crisis", Journal of Financial Economics, Vol. 58 No. 1-2, pp. 141-186.

Khandker, S.R. (2005), "Microfinance and poverty: Evidence using panel data from Bangladesh", World Bank Economic Review, Vol. 19 No. 2, pp. 263-286.

Kono, H. and Takahashi, K. (2010), "Microfinance revolution: Its effects, innovations, and challenges", Developing Economies, Vol. 48 No. 1, pp. 15-73.

Kuhn, T. and Hacking, I. (2012), The Structure of Scientific Revolutions, The Structure of Scientific Revolutions, 4th ed., University of Chicago Press, Chicago.

Kyereboah-Coleman, A. (2007a), "The determinants of capital structure of microfinance institutions in Ghana", South African Journal of Economic and Management Sciences, Vol. 10 No. 2, pp. 270-279.

Kyereboah-Coleman, A. (2007b), "The impact of capital structure on the performance of microfinance institutions", The Journal of Risk Finance, Vol. 8 No. 1, pp. 57-71.

Kyereboah-Coleman, A. and Osei, K.A. (2008), "Outreach and profitability of microfinance institutions: the role of governance", Journal of Economic Studies, Vol. 35 No. 5, pp. 236-248.

Labie, M. (2001), "Corporate governance in microfinance organizations: along and winding road", Management Decision, Vol. 39 No. 4, pp. 296-302. 
Labie, M. and Mersland, R. (2011), "Corporate governance challenges in microfinance", in Armendariz, B. and Labie, M. (Eds.), The Handbook of Microfinance, World Scientific Publishing, Singapore, pp. 283-298.

Ledgerwood, J. (1999), Sustainable Banking with the Poor Microfinance Handbook: An Institutional and Financial Perspective, The World Bank, Washington, DC.

Lensink, R., Mersland, R., Vu, N.T.H. and Zamore, S. (2018), "Do microfinance institutions benefit from integrating financial and nonfinancial services?", Applied Economics, Vol. 50 No. 21, pp. $2386-2401$.

Meho, L.I. and Rogers, Y. (2008), "Citation counting, citation ranking, and h-index of humancomputer interaction researchers: A comparison of scopus and web of science", Journal of the American Society for Information Science and Technology, Vol. 59 No. 11, pp. 1711-1726.

Mersland, R. (2011), “The governance of non-profit micro finance institutions: lessons from history", Journal of Management \& Governance, Vol. 15, pp. 3-4.

Mersland, R. (2013), "Market opportunities for microfinance institutions", in Mersland, R. (Ed.), Enterprise Development and Microfinance, Practical Action Publishing, pp. 282-294.

Mersland, R., Randøy, T. and Strøm, R.Ø. (2011), "The impact of international influence on microbanks' performance: A global survey”, International Business Review, Vol. 20 No. 2, pp. $163-176$.

Mersland, R. and Strøm, Ø.R. (2009), "Performance and governance in microfinance institutions", Journal of Banking \& Finance, Vol. 33 No. 4, pp. 662-669.

Mersland, R. and Strøm, R.Ø. (2008), "Performance and trade-offs in microfinance organizationsdoes ownership matter?”, Journal of International Development, Vol. 20 No. 4, pp. 598-612.

Mia, A. (2016), "Microfinance Institutions and Legal Status: An Overview of the Microfinance Sector in Bangladesh", Journal of Asian Finance, Economics and Busines, Vol. 3 No. 2, pp. 21-31.

Mia, M.A., Lee, H.A., Chandran, V., Rasiah, R. and Rahman, M. (2019), "History of microfinance in Bangladesh: A life cycle theory approach", Business History, Vol. 61 No. 4, pp. 703-733.

Mia, M.A., Nasrin, S. and Cheng, Z. (2016), "Quality, quantity and financial sustainability of microfinance: Does resource allocation matter?", Quality and Quantity, Vol. 50 No. 3, pp. $1285-1298$.

Mia, M.A., Zhang, M., Zhang, C. and Kim, Y. (2018), “Are microfinance institutions in South-East Asia pursuing objectives of greening the environment?", Journal of the Asia Pacific Economy, Taylor \& Francis, Vol. 23 No. 2, pp. 229-245.

Morduch, J. (1999), “The microfinance promise”, Journal of Economic Literature, Vol. 37 No. 4, pp. $1569-1614$.

Mori, N. (2010), "Roles of stakeholders in strategic decision-making of microfinance organizations", International Business \& Economics Research Journal, Vol. 9 No. 7, pp. 51-63.

Mori, N. and Charles, G. (2018), "The role of boards of directors of family-owned microfinance institutions", Journal of Family Business Management, Vol. 9 No. 1, pp. 79-97.

Mori, N., Golesorkhi, S., Randøy, T. and Hermes, N. (2015), "Board Composition and Outreach Performance of Microfinance Institutions: Evidence from East Africa", Strategic Change, Vol. 24 No. 1, pp. 99-113. 
Mori, N. and Mersland, R. (2014), "Boards in microfinance institutions: how do stakeholders matter?", Journal of Management and Governance, Vol. 18 No. 1, pp. 285-313.

Mori, N., Randøy, T. and Golesorkhi, S. (2013), "Determinants of board structure in microfinance institutions: evidence from East Africa", Journal of Emerging Market Finance, Vol. 12 No. 3, pp. 323-365.

Nalukenge, I., Tauringana, V. and Ntayi, J.M. (2017), "Corporate governance and internal controls over financial reporting in Ugandan MFIs", Journal of Accounting in Emerging Economies, Vol. 7 No. 3, pp. 294-317.

Nawaz, A., Iqbal, S. and Ehsan, S. (2018), "Does social performance drive corporate governance mechanism in case of Asian MFIs? An issue of endogeneity", Global Business Review, Vol. 19 No. 4, pp. 988-1012.

Ndaki, P.D., Beisland, A.L. and Mersland, R. (2018), "Capital structure and CEO tenure in microfinance institutions”, Strategic Change, Vol. 27 No. 4, pp. 329-337.

Nihel, H. and Younes, B. (2015), "External governance and dual mission in the African MFIs", Strategic Change, Vol. 24 No. 3, pp. 243-265.

Nørreklit, L., Nørreklit, H. and Israelsen, P. (2006), "The validity of management control topoi", Management Accounting Research, Vol. 17 No. 1, pp. 42-71.

Pascal, D., Mersland, R. and Mori, N. (2017), "The influence of the CEO's business education on the performance of hybrid organizations: the case of the global microfinance industry", Small Business Economics, Vol. 49 No. 2, pp. 339-354.

Phillips, W., Lee, H., Ghobadian, A. and James, P. (2015), "Social Innovation and Social Entrepreneurship: A Systematic Review", Group \& Organization Management, Vol. 40 No. 3, pp. $428-461$.

Quayes, S. and Hasan, T. (2014), "Financial disclosure and performance of microfinance institutions", Journal of Accounting \& Organizational Change, Vol. 10 No. 8, pp. 314-337.

Raihan, S., Osmani, S.R. and Khalily, M.A.A.B. (2017), "The macro impact of microfinance in Bangladesh: a CGE analysis", Economic Modelling, Vol. 62, pp. 1-15.

Rajbanshi, R., Huang, M. and Wydick, B. (2015), "Measuring microfinance : assessing the conflict between practitioners and researchers with evidence from Nepal", World Development, Vol. 68, pp. 30-47.

Randøy, T., Strøm, R.Ø. and Mersland, R. (2013), “The impact of entrepreneur-CEOs in microfinance institutions: a global survey", Entrepreneurship, Theory and Practice, Vol. 39 No. 4, pp. $927-$ 953.

Van Rooyen, C., Stewart, R. and de Wet, T. (2012), "The impact of microfinance in Sub-Saharan Africa: a systematic review of the evidence", World Development, Vol. 40 No. 11, pp. 2249 2262 .

Saeed, A., Javed, A.Y. and Noreen, U. (2018), "Microfinancing, governance, and performance: a South Asian perspective", Journal of Economics, Finance and Administrative Science, Vol. 23 No. 46, pp. 247-265.

Saraswathy-Amma, K.P., Kannan, G. and Parthasarathy, L. (2019), "Do regulations and governance quality impact performance of MFIs in India?", DECISION, Vol. 46 No. 1, pp. 3-14.

Schultz, E.L., Tan, D.T. and Walsh, K.D. (2010), "Endogeneity and the corporate governance- 
performance relation”, Australian Journal of Management, Vol. 35 No. 2, pp. 145-163.

Seibel, H.D. (2005), Does History Matter? The Old and the New World of Microfinance in Europe and Asia, No. 2005,10, Universität zu Köln, Arbeitsstelle für Entwicklungsländerforschung (AEF), Köln.

Sengupta, R. and Aubuchon, C.P. (2008), "The microfinance revolution: an overview", Federal Reserve Bank of St. Louis Review, Vol. 90 No. 1, pp. 9-30.

Servin, R., Lensink, R. and van den Berg, M. (2012), "Ownership and technical efficiency of microfinance institutions: Empirical evidence from Latin America", Journal of Banking \& Finance, Vol. 36 No. 7, pp. 2136-2144.

Shahriar, A.Z.M., Schwarz, S. and Newman, A. (2015), "Profit orientation of microfinance institutions and provision of financial capital to business start-ups", International Small Business Journal, Vol. 34 No. 4, pp. 532-552.

Shettima, U. and Dzolkarnaini, N. (2018), "Board characteristics and microfinance institutions' performance: Panel data evidence from Nigeria", Journal of Accounting in Emerging Economies, Vol. 8 No. 3, pp. 369-386.

Singh, A. (2003), "Competition, corporate governance and selection in emerging markets", Economic Journal, Vol. 113 No. 491, pp. F443-F464.

Siwale, J. and Okoye, N. (2017), "Microfinance regulation and social sustainability of microfinance institutions: the case of Nigeria and Zambia", Annals of Public and Cooperative Economics, Vol. 88 No. 4, pp. 611-632.

Strøm, Ø.R., Espallier, B.D. and Mersland, R. (2014), "Female leadership, performance, and governance in microfinance institutions", Journal of Banking \& Finance, Vol. 42 No. 1, pp. 60 75.

Tanin, T.I., Mobin, M.A., Ng, A., Dewandaru, G., Salim, K., Nkoba, M.A. and Abdul Razak, L. (2019), "How does microfinance prosper? An analysis of environmental, social, and governance context", Sustainable Development, pp. 01-22.

Tchakoute-Tchuigoua, H. (2010), "Is there a difference in performance by the legal status of microfinance institutions?", Quarterly Review of Economics and Finance, Vol. 50 No. 4, pp. 436-442.

Tchakoute-Tchuigoua, H., François, D. and Guy, S.K. (2017), "Funding strategy and performance of microfinance institutions: an exploratory study", Strategic Change, Vol. 26 No. 2, pp. 133-143.

Tchakoute Tchuigoua, H. (2015), "Determinants of the governance quality of microfinance institutions", Quarterly Review of Economics and Finance, Vol. 58, pp. 32-43.

Thrikawala, S., Locke, S. and Reddy, K. (2016a), "Board structure-performance relationship in microfinance institutions (MFIs) in an emerging economy", Corporate Governance: The International Journal of Business in Society, Vol. 16 No. 5, pp. 815-830.

Thrikawala, S., Locke, S. and Reddy, K. (2016b), "Corporate governance practices and performance of microfinance sector", in Klein, E. (Ed.), Corporate Governance: Principles, Practices and Challenges, Nova Science Publishers, Inc., New York, pp. 33-83.

Thrikawala, S.S., Locke, S. and Reddy, K. (2015), "An empirical analysis of corporate governance impact on outreach of microfinance institutions (MFIs)", Corporate Ownership and Control, Vol. 13 No. 1, pp. 8-14. 
Thrikawala, S.S., Locke, S. and Reddy, K. (2017), "Dynamic endogeneity and corporate governance performance relationship : lessons from the microfinance sector", Journal of Economic Studies, Vol. 44 No. 5, pp. 01-33.

Tilakaratna, G. and Hulme, D. (2015), "Microfinance and Multiple Borrowing in Sri Lanka : Another Microcredit Bubble in South Asia ?", South Asia Economic Journal, Vol. 16 No. 1, pp. 46-63.

Tranfield, D., Denyer, D. and Smart, P. (2003), "Towards a methodology for developing evidenceinformed management knowledge by means of systematic review", British Journal of Management, Vol. 14 No. 3, pp. 207-222.

Wale, L.E. (2015), "Board diversity, external governance, ownership structure and performance in Ethiopian microfinance institutions", Corporate Ownership and Control, Vol. 12 No. 3, pp. 190-200.

Walls, J.L., Berrone, P. and Phan, P.H. (2012), "Corporate governance and environmental performance: Is there really a link?”, Strategic Management Journal, Vol. 33 No. 8, pp. 885913.

Wamba, L.D., Bengono, I.B., Sahut, J.M. and Teulon, F. (2018), "Governance and performance of MFIs: the Cameroon case", Journal of Management and Governance, Vol. 22 No. 1, pp. 7-30.

Weir, C., Laing, D. and McKnight, P.J. (2002), "Internal and external governance mechanisms: their impact on the performance of large UK public companies", Journal of Business Finance \& Accounting, Vol. 29 No. 5-6, pp. 579-611.

Win, S. and Kofinas, A.K. (2019), "Reflecting and Integrating the Contextual Influences of Ambiguities and Institutional Power in Organisational Research Design: A Case of Myanmar", Management and Organization Review, Vol. 15 No. 2, pp. 341-370.

Wintoki, M.B., Linck, J.S. and Netter, J.M. (2012), "Endogeneity and the dynamics of internal corporate governance", Journal of Financial Economics, North-Holland, Vol. 105 No. 3, pp. 581-606.

Yunus, M. (2003), Banker to the Poor: Micro-Lending and the Battle Against World Poverty, Public Affairs, New York.

Zulfiqar, G. (2017), "Does microfinance enhance gender equity in access to finance? evidence from Pakistan", Feminist Economics, Vol. 23 No. 1, pp. 160-185. 


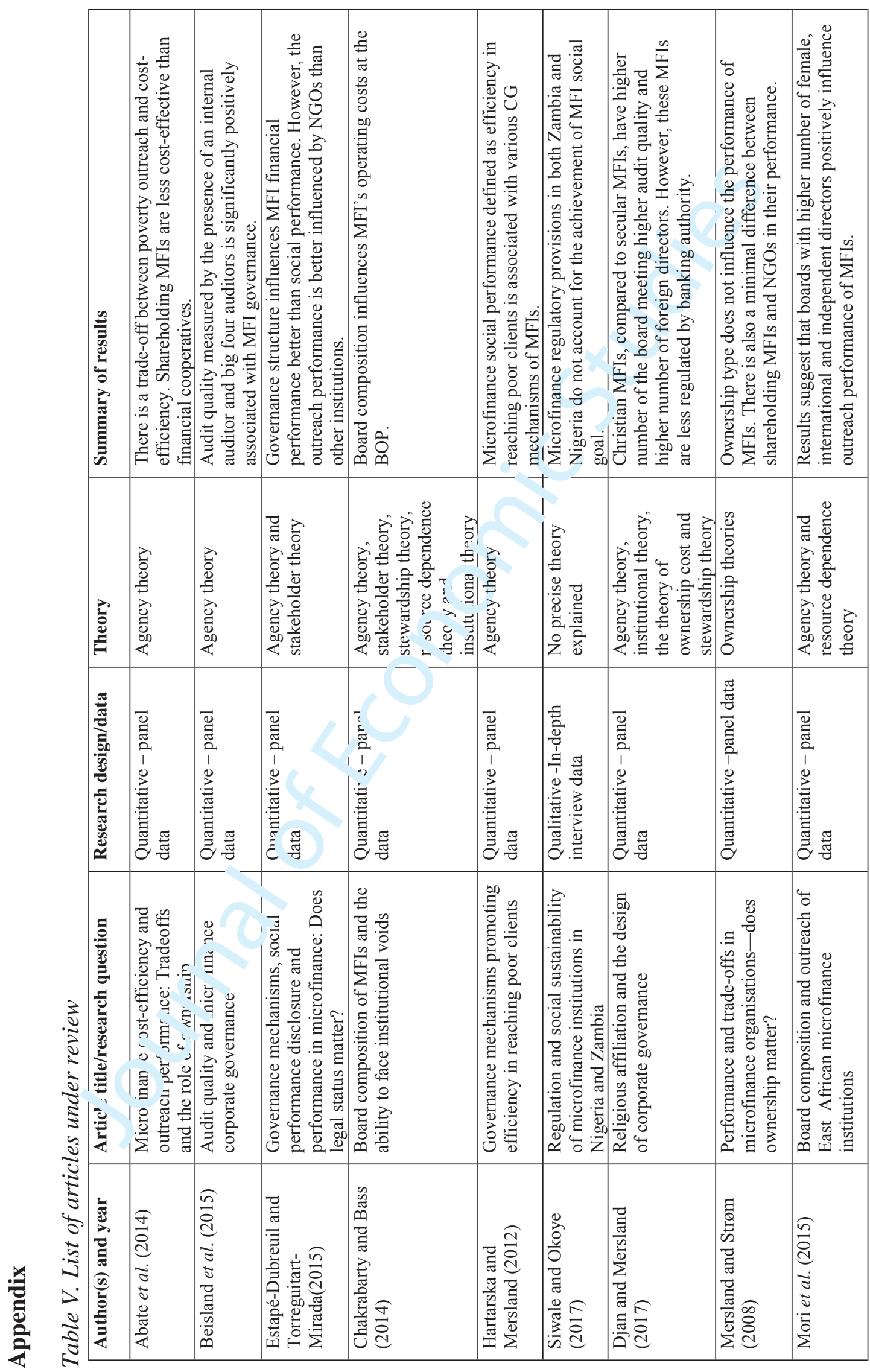

จ 


\begin{tabular}{|c|c|c|c|c|c|c|c|c|c|c|}
\hline 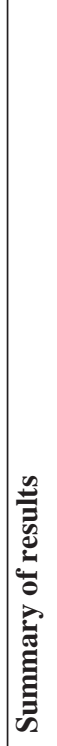 & 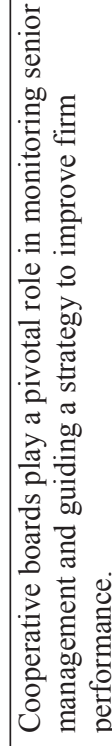 & 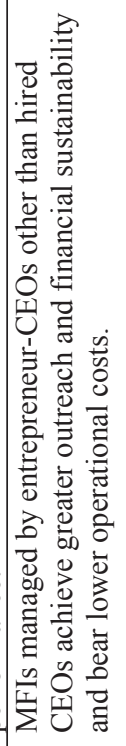 & 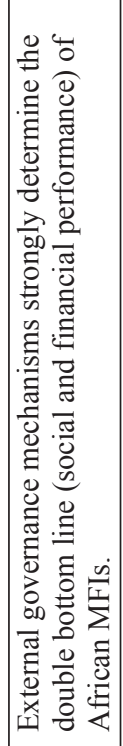 & 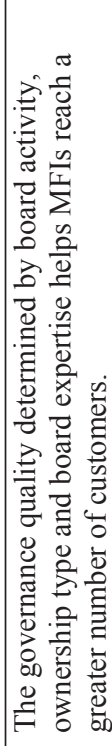 & 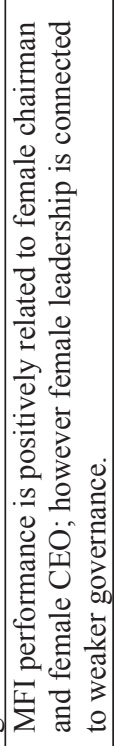 & 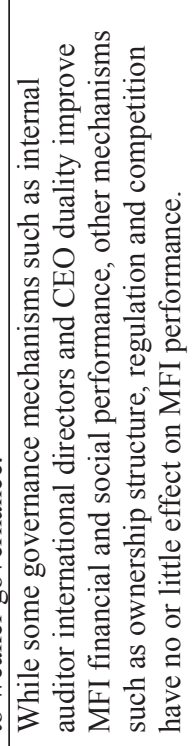 & 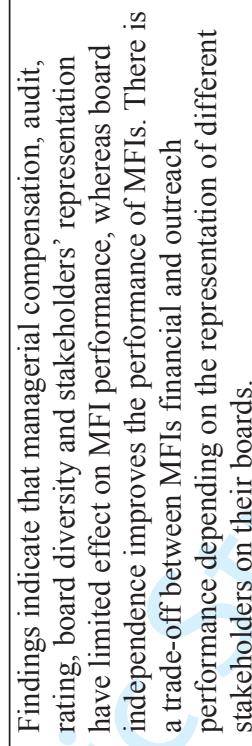 & 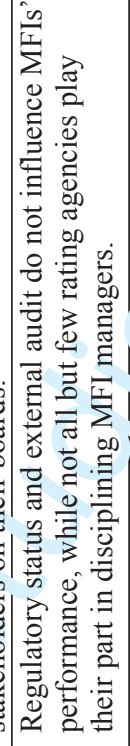 & 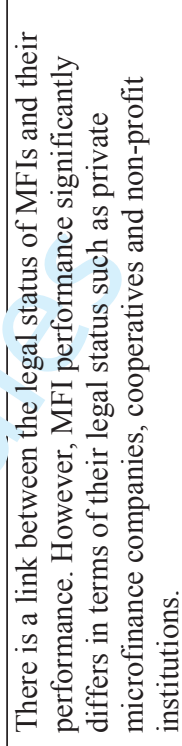 & 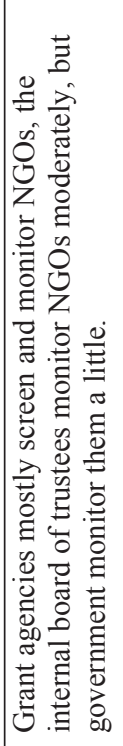 \\
\hline 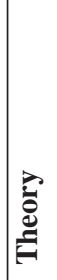 & 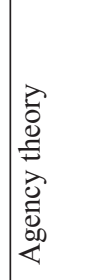 & 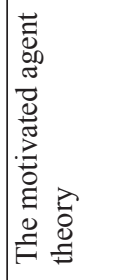 & 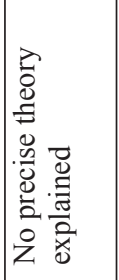 & 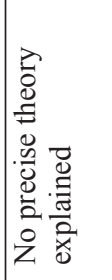 & 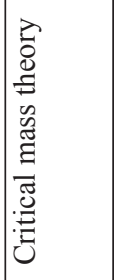 & 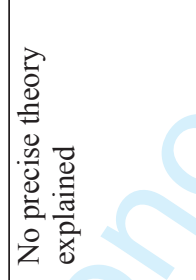 & 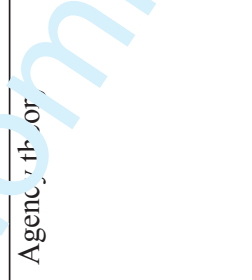 & 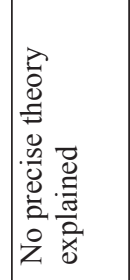 & 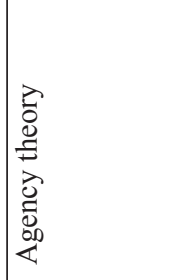 & 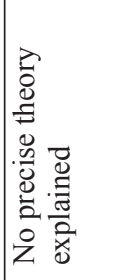 \\
\hline 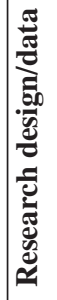 & 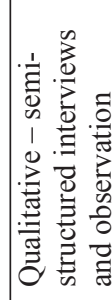 & 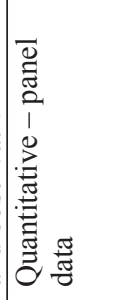 & 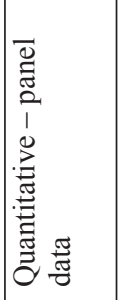 & 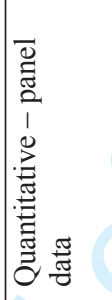 & 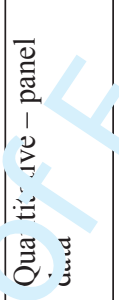 & 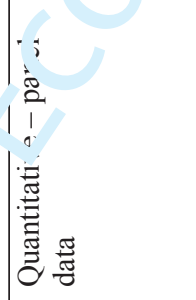 & 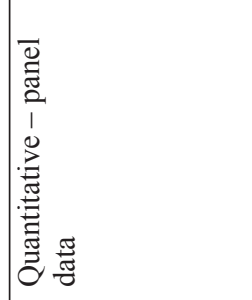 & 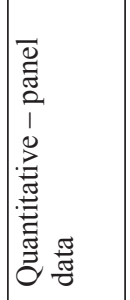 & 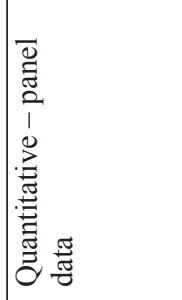 & 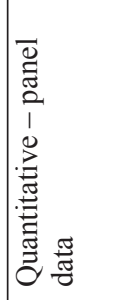 \\
\hline 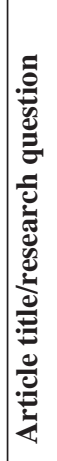 & 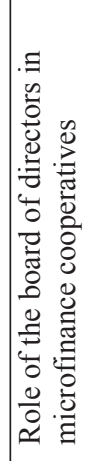 & 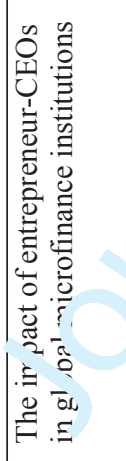 & 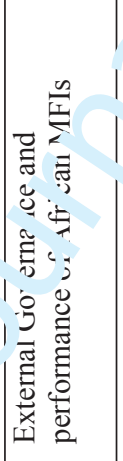 & 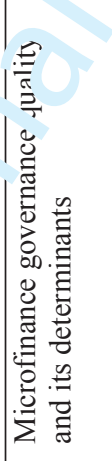 & 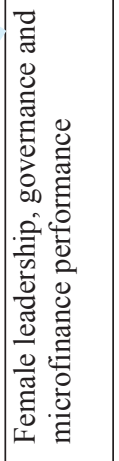 & 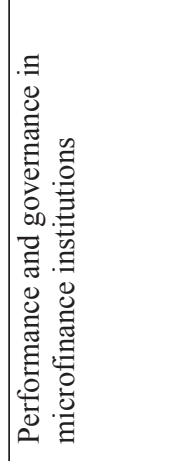 & 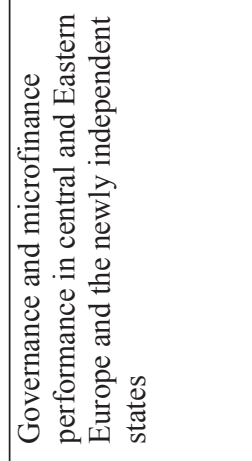 & 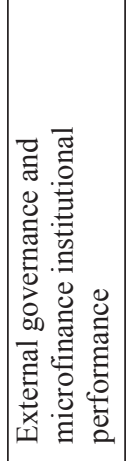 & 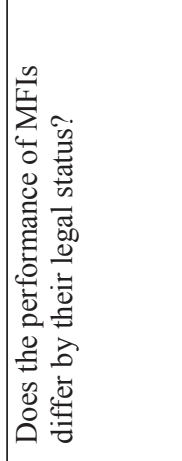 & 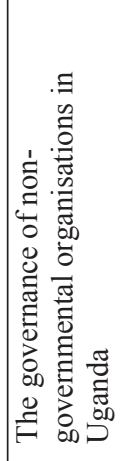 \\
\hline 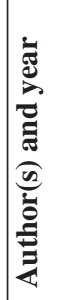 & 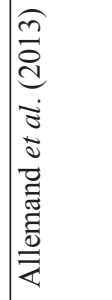 & 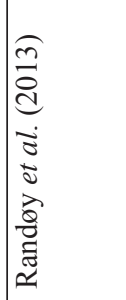 & 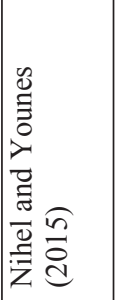 & 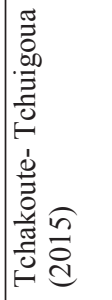 & 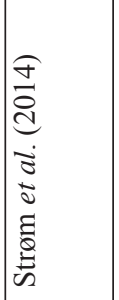 & 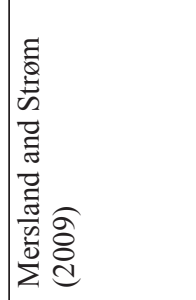 & 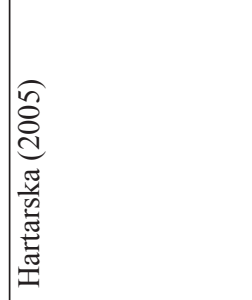 & 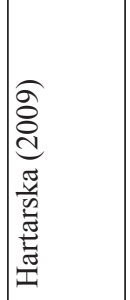 & 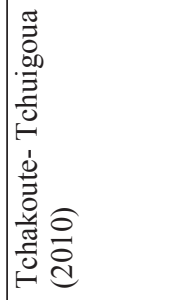 & 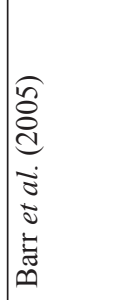 \\
\hline
\end{tabular}




\begin{tabular}{|c|c|c|c|c|c|c|c|c|c|c|}
\hline 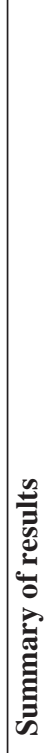 & 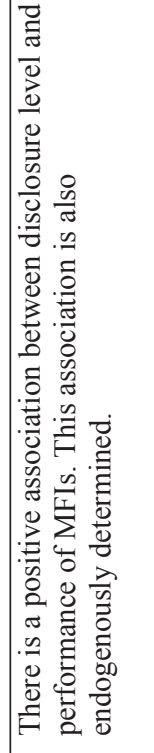 & 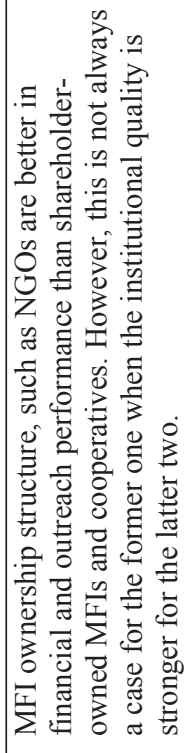 & 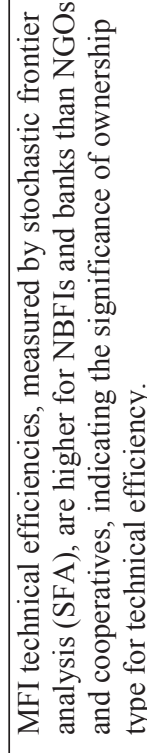 & 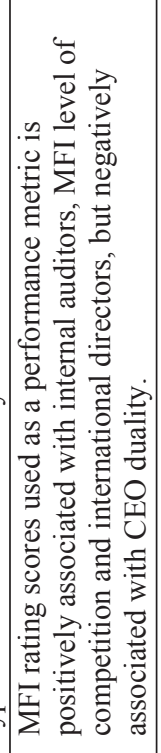 & 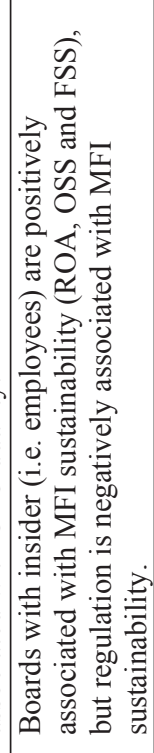 & 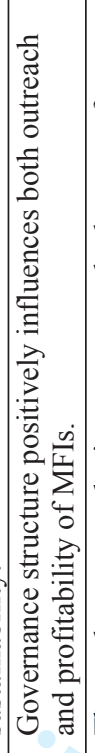 & 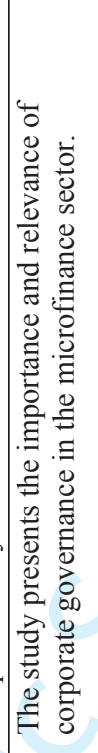 & 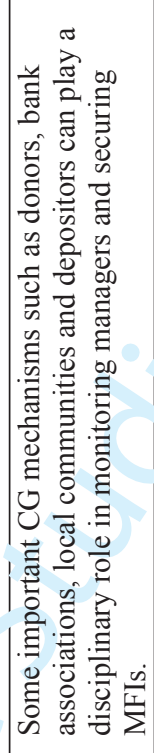 & 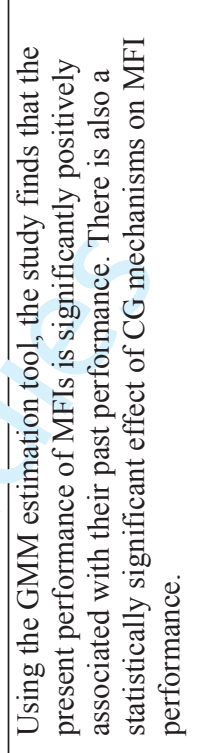 & 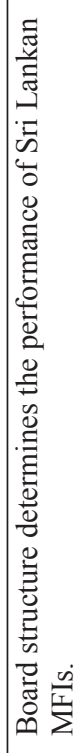 \\
\hline : & 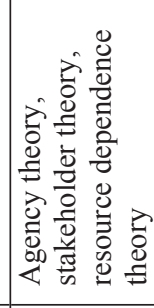 & 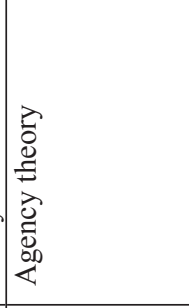 & 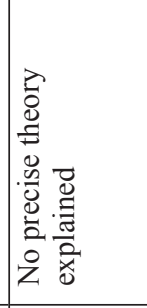 & 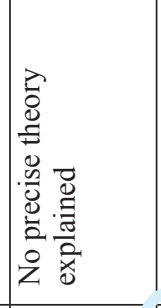 & 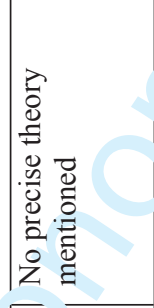 & 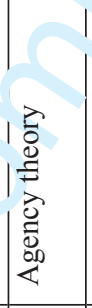 & 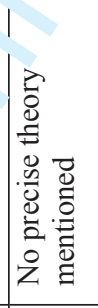 & 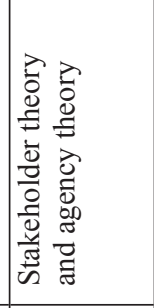 & 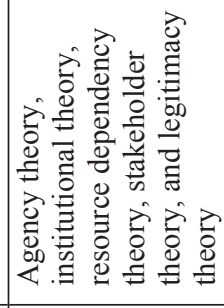 & 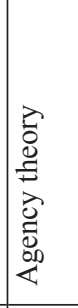 \\
\hline 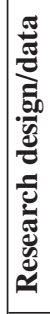 & 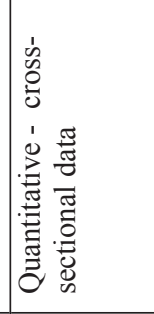 & 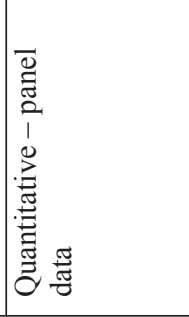 & 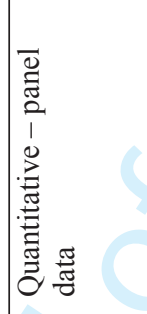 & 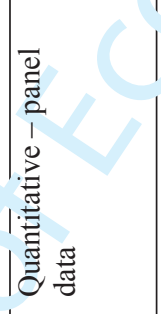 & 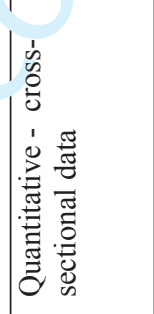 & 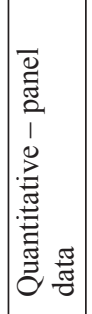 & 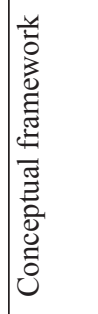 & 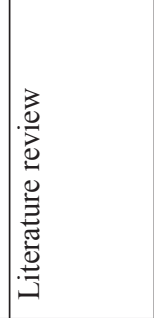 & 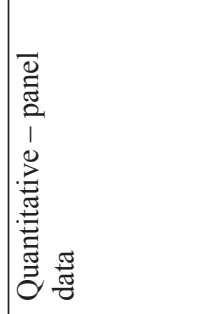 & 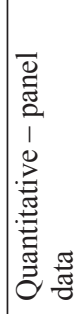 \\
\hline 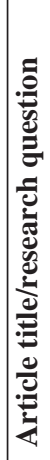 & 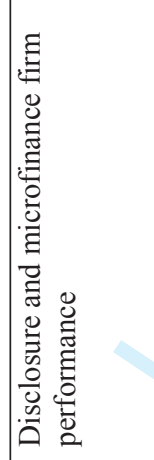 & 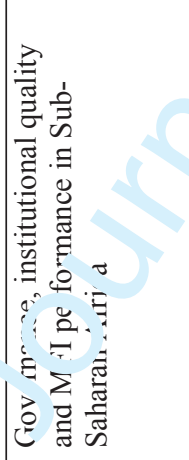 & 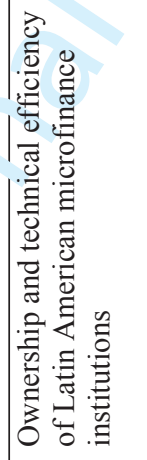 & 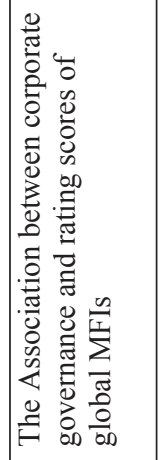 & 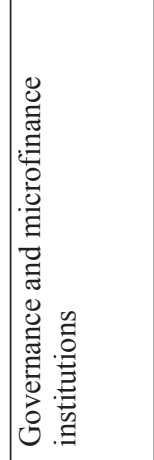 & 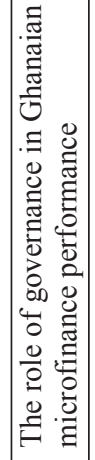 & 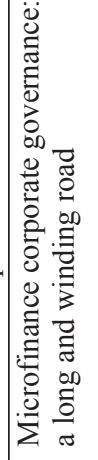 & 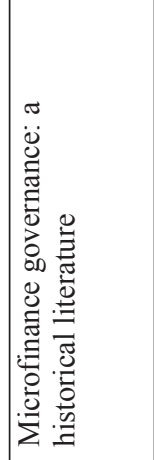 & 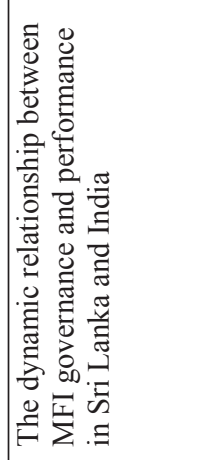 & 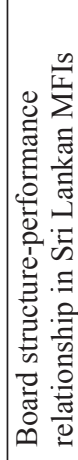 \\
\hline 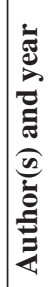 & 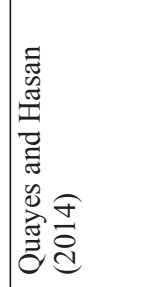 & 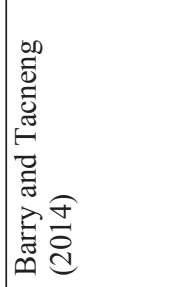 & 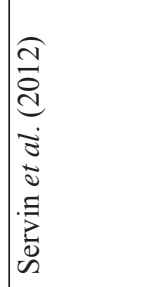 & 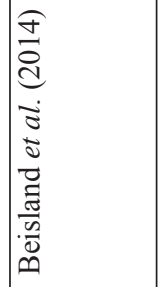 & 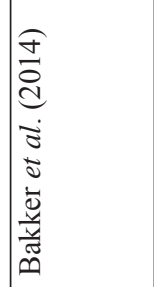 & 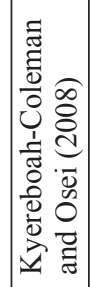 & 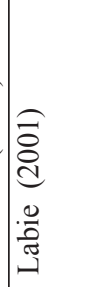 & 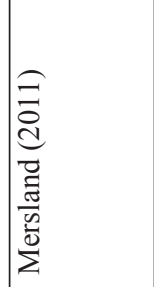 & 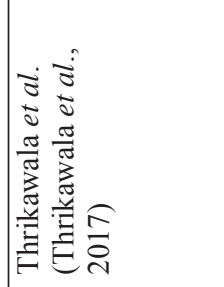 & 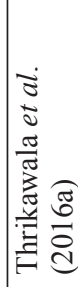 \\
\hline
\end{tabular}

하 


\begin{tabular}{|c|c|c|c|c|c|c|c|c|c|}
\hline 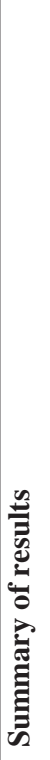 & 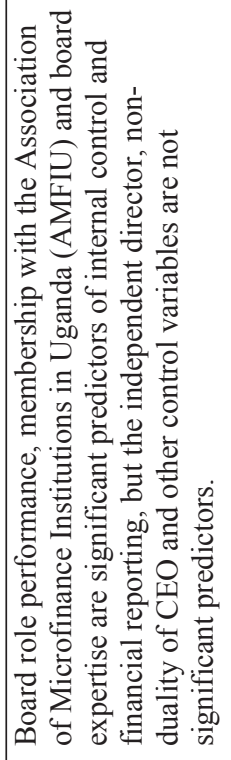 & 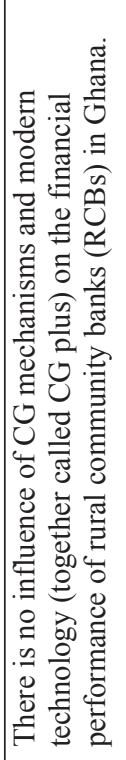 & 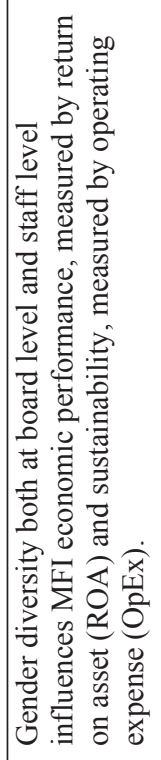 & 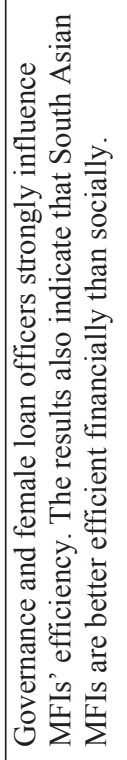 & 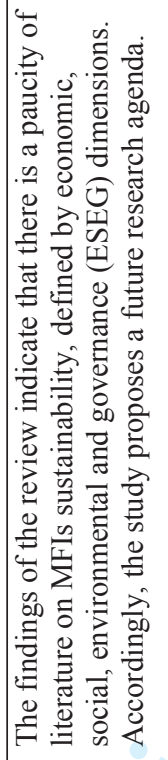 & 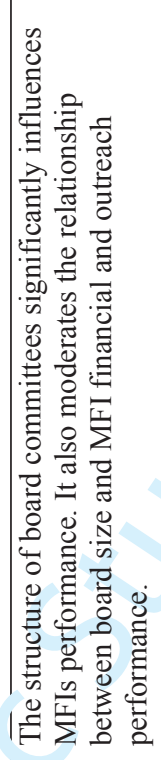 & 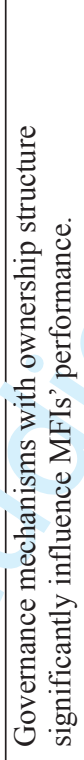 & 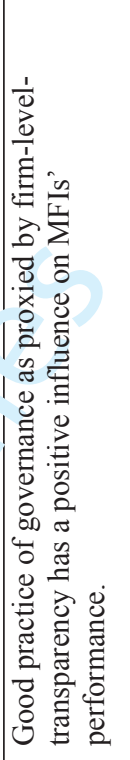 & 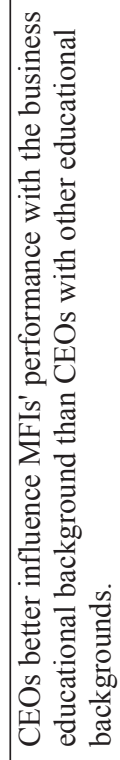 \\
\hline 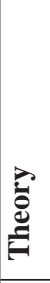 & 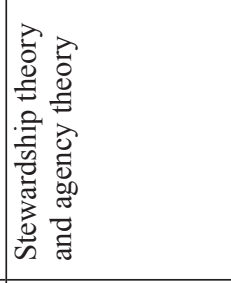 & 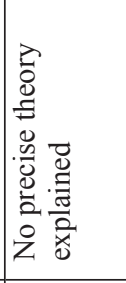 & 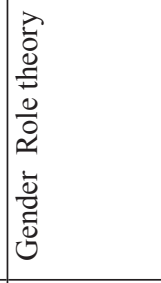 & 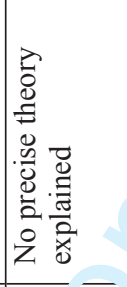 & 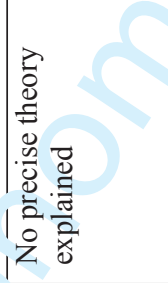 & 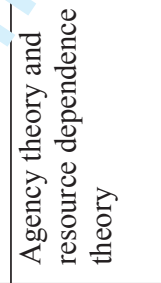 & 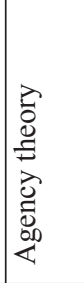 & 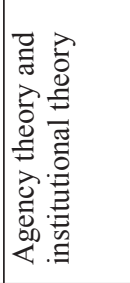 & 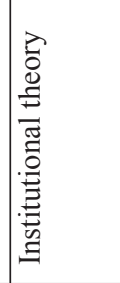 \\
\hline 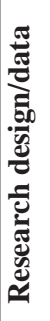 & 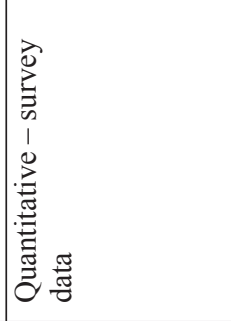 & 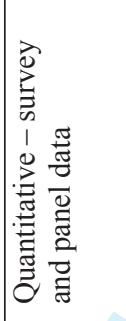 & 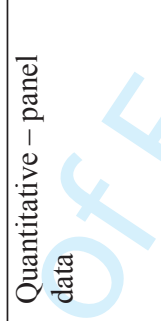 & 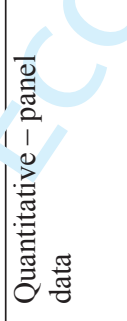 & 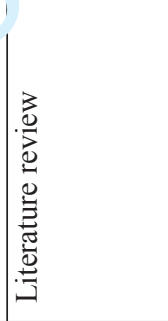 & 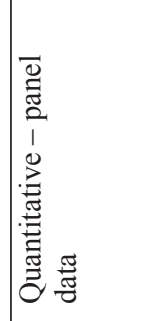 & 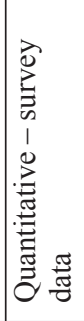 & 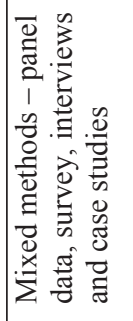 & 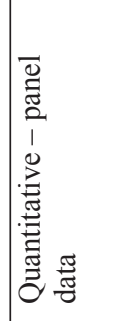 \\
\hline 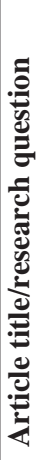 & 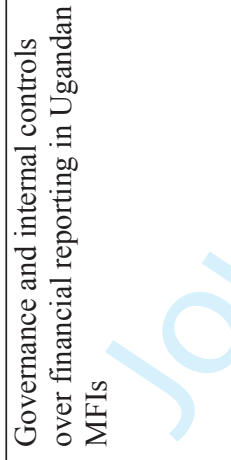 & 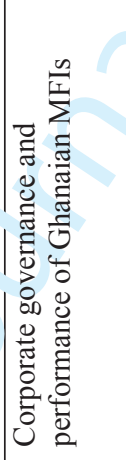 & 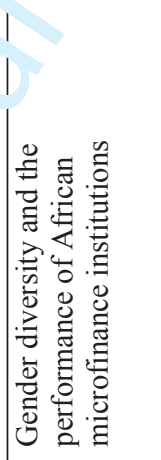 & 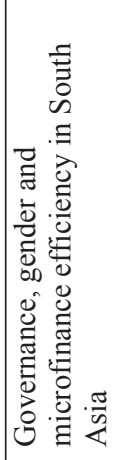 & 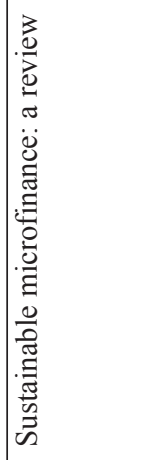 & 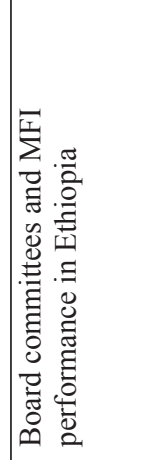 & 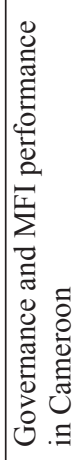 & 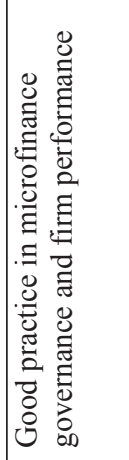 & 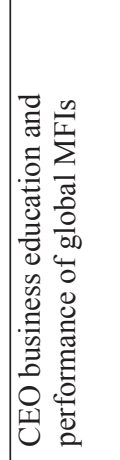 \\
\hline & 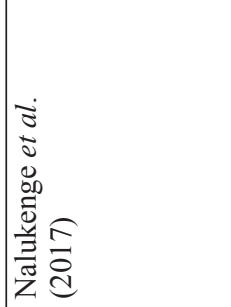 & 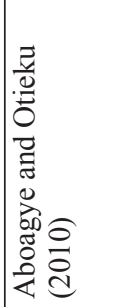 & 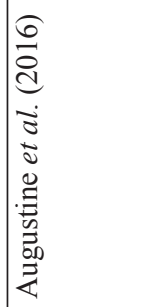 & 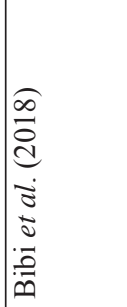 & 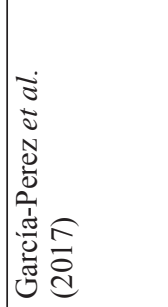 & 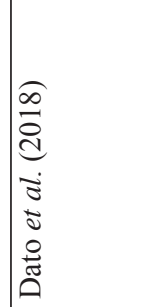 & 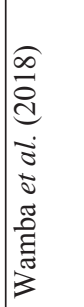 & 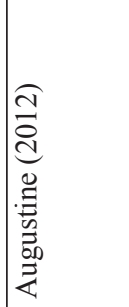 & 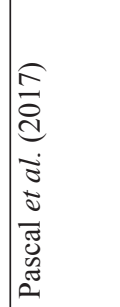 \\
\hline
\end{tabular}




\begin{tabular}{|c|c|c|c|c|c|c|c|c|c|}
\hline 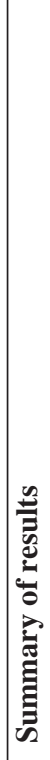 & 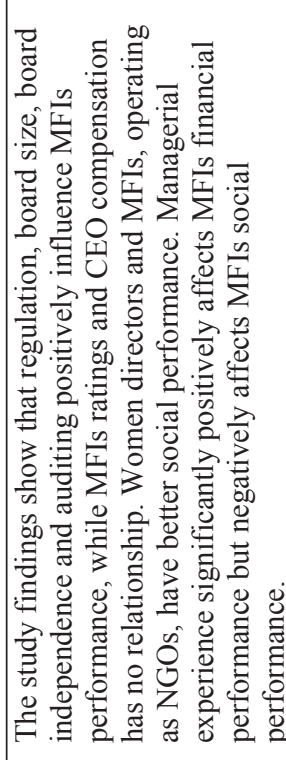 & 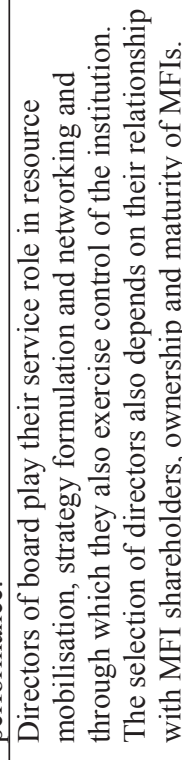 & 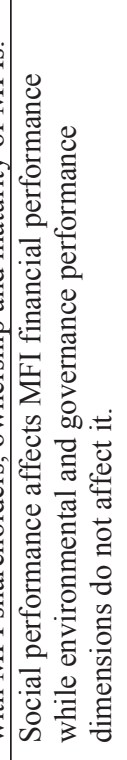 & 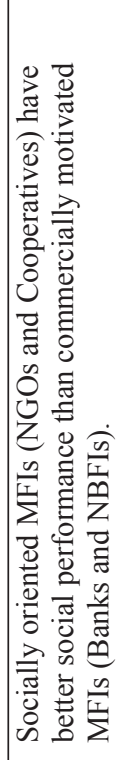 & 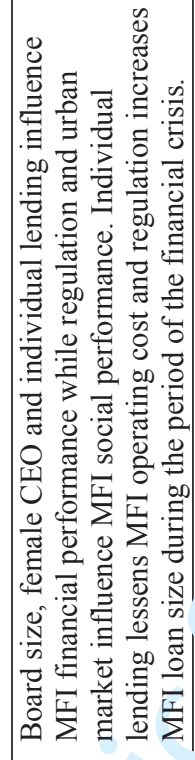 & 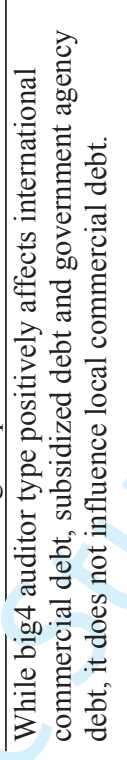 & 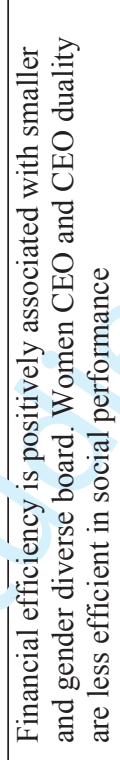 & 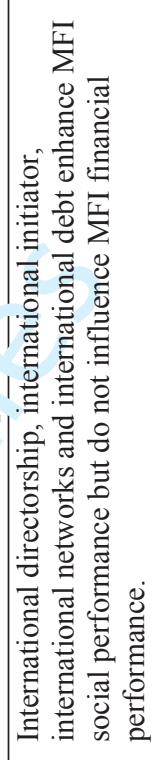 & 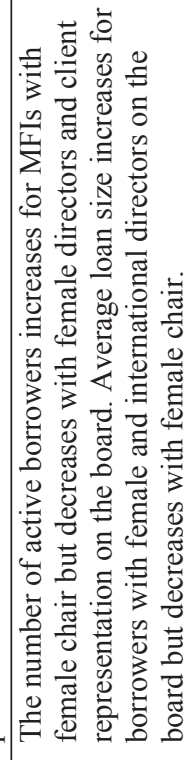 \\
\hline 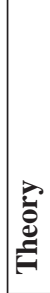 & 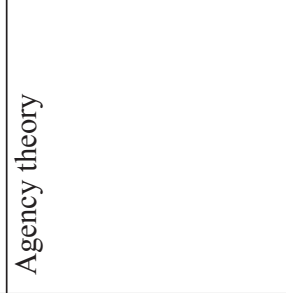 & 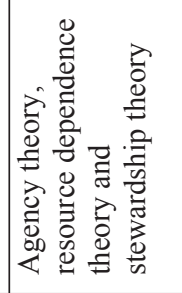 & 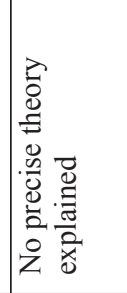 & 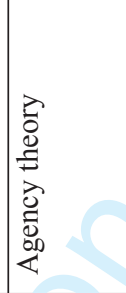 & 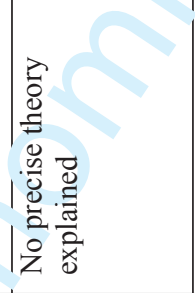 & 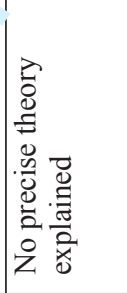 & 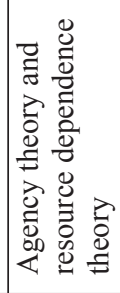 & 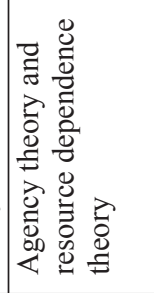 & 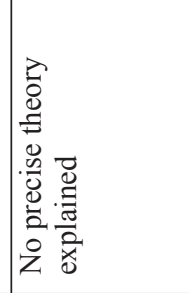 \\
\hline 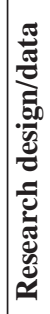 & 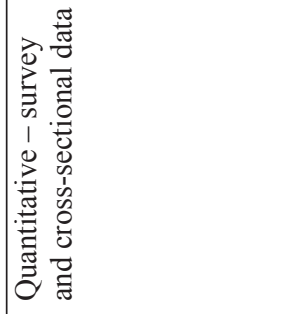 & 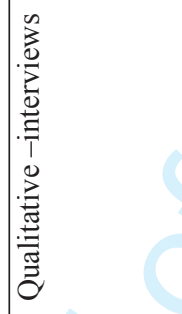 & 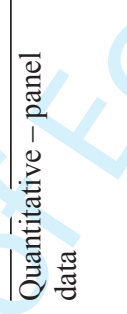 & 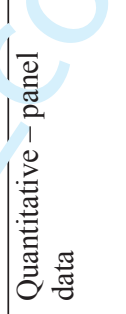 & 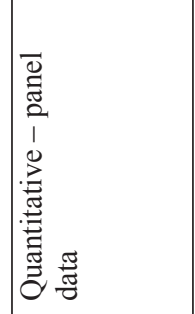 & 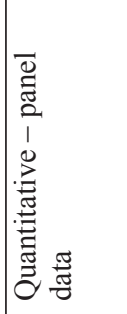 & 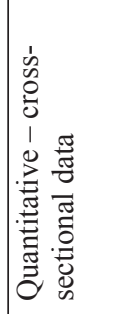 & 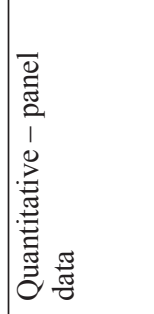 & 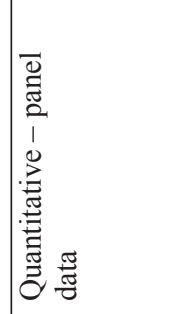 \\
\hline 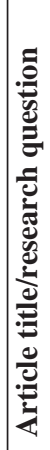 & 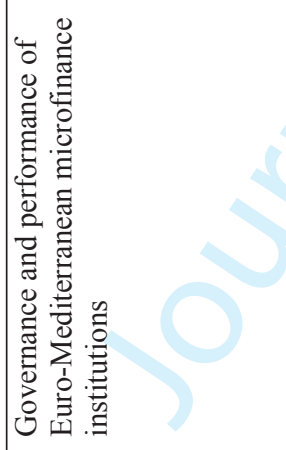 & 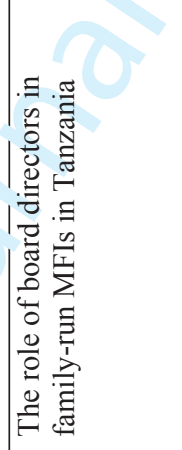 & 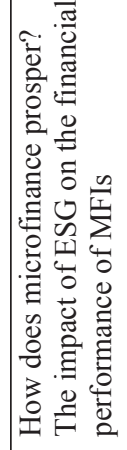 & 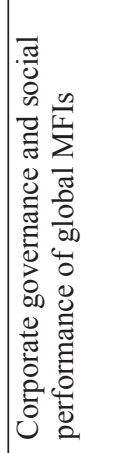 & 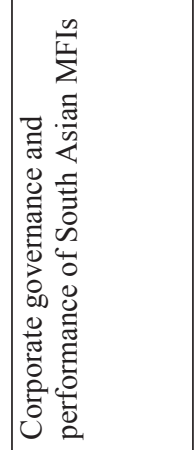 & 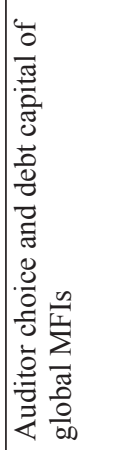 & 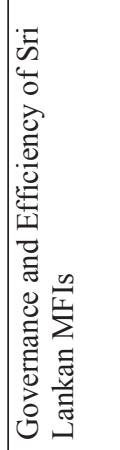 & 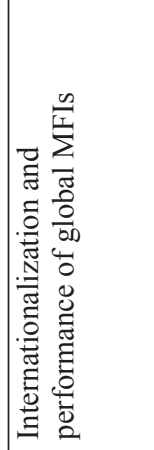 & 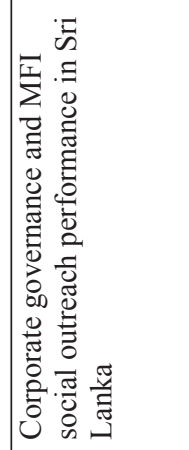 \\
\hline 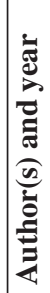 & 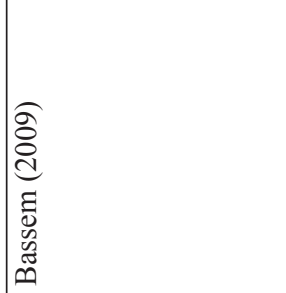 & 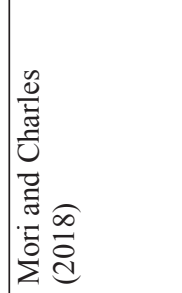 & 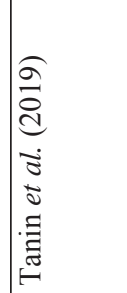 & 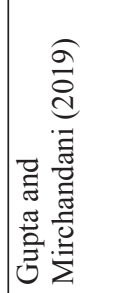 & 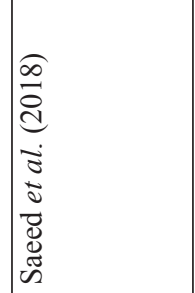 & 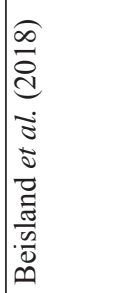 & 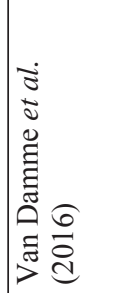 & 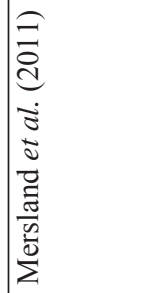 & 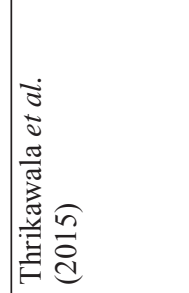 \\
\hline
\end{tabular}

$m$ 


\begin{tabular}{|c|c|c|c|c|c|c|c|c|c|c|c|}
\hline 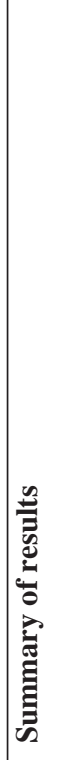 & 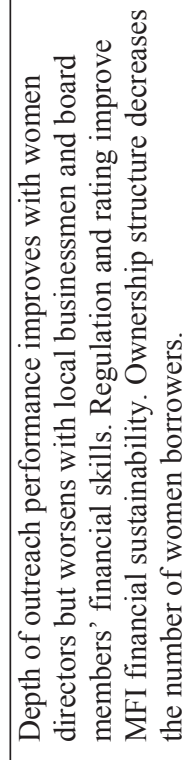 & 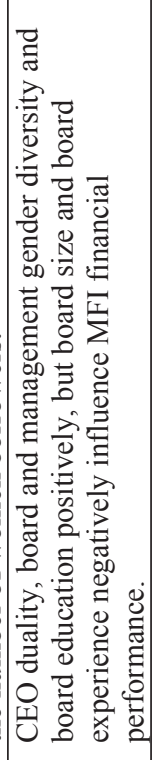 & 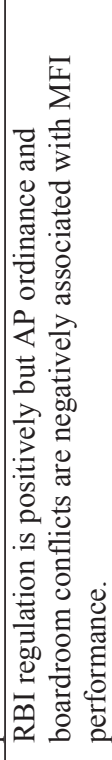 & 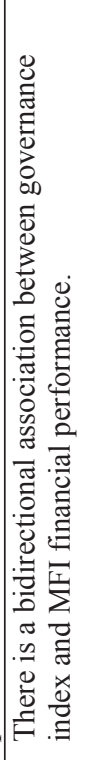 & 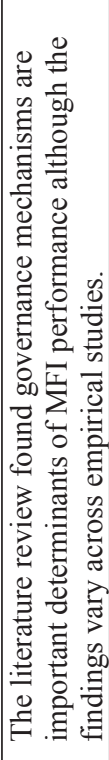 & 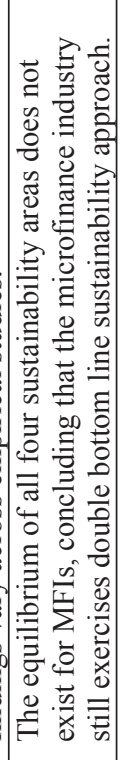 & 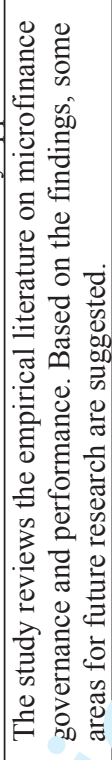 & 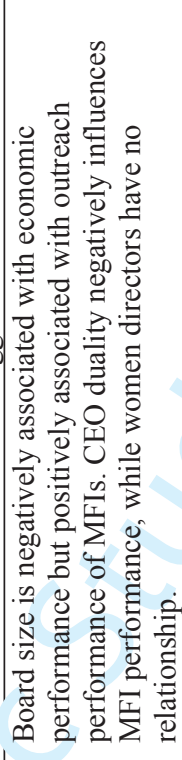 & 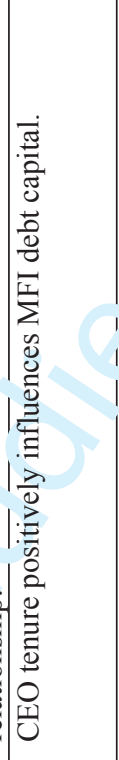 & 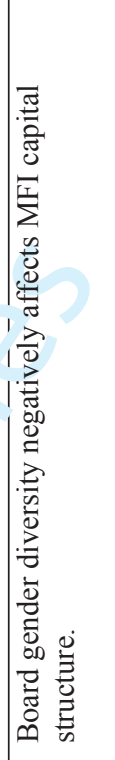 & 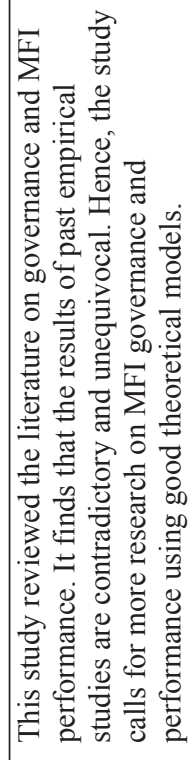 \\
\hline 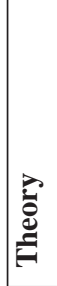 & 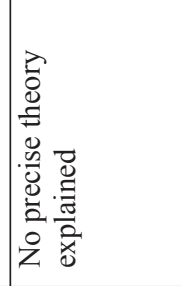 & 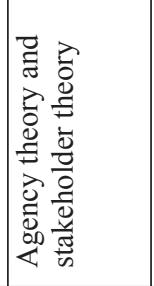 & 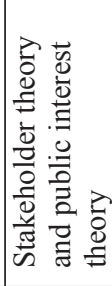 & 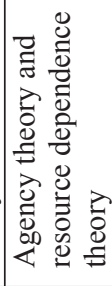 & 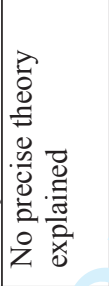 & 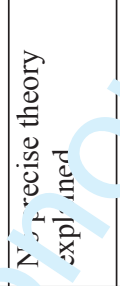 & 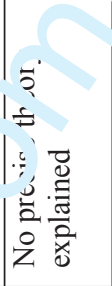 & 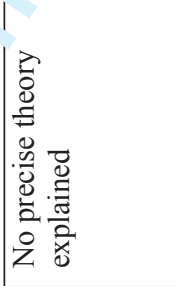 & 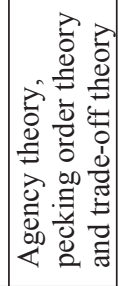 & 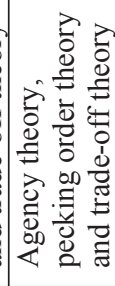 & 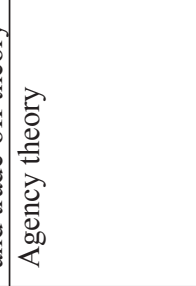 \\
\hline 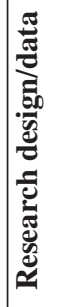 & 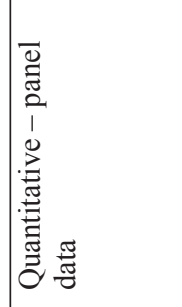 & 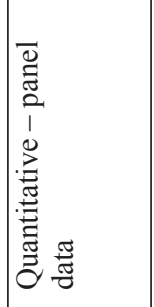 & 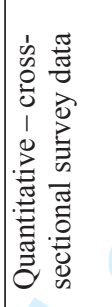 & 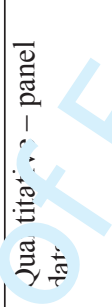 & 产 & 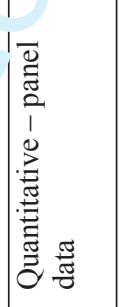 & 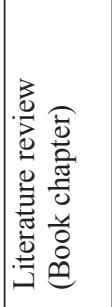 & 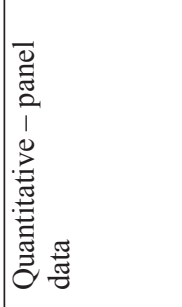 & 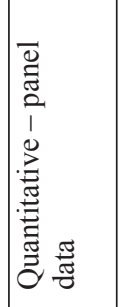 & 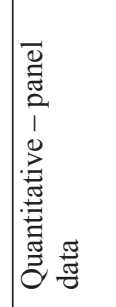 & 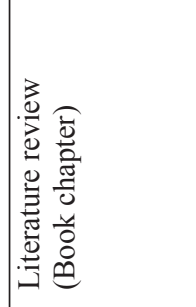 \\
\hline 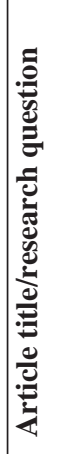 & 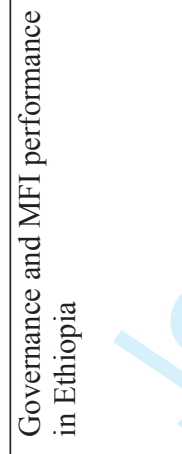 & 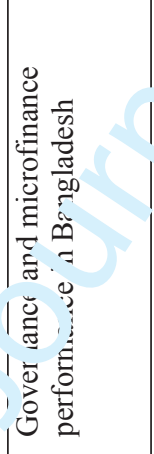 & 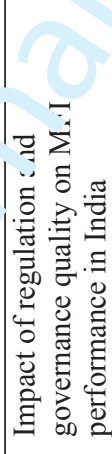 & 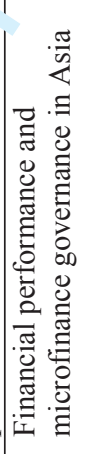 & 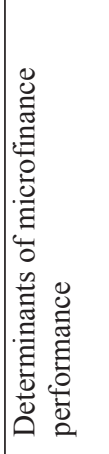 & 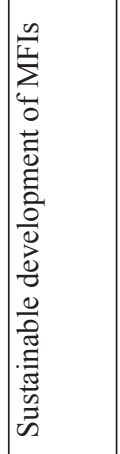 & 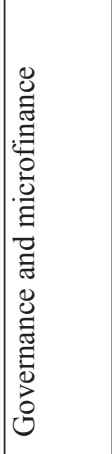 & 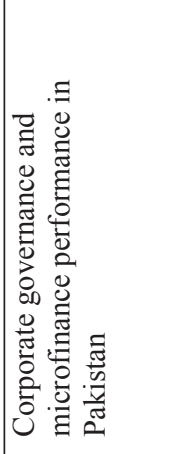 & 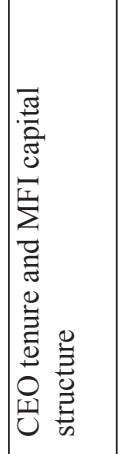 & 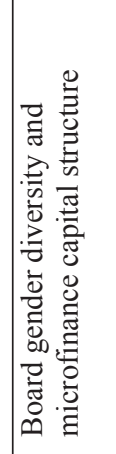 & 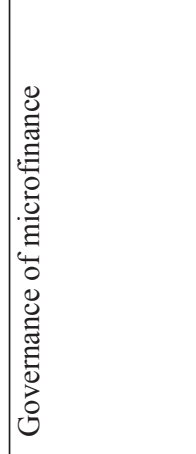 \\
\hline 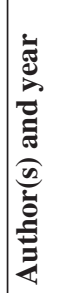 & $\mid \begin{array}{l}\frac{\pi}{2} \\
\stackrel{d}{d} \\
\frac{0}{\pi} \\
\frac{\pi}{3}\end{array}$ & 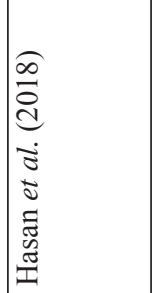 & 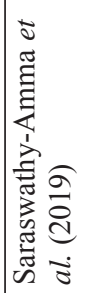 & 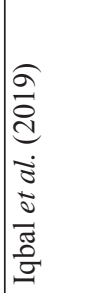 & 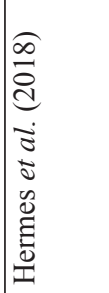 & 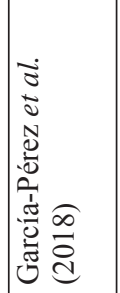 & 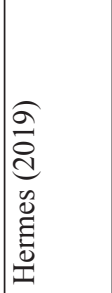 & 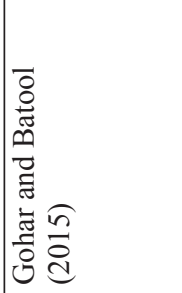 & 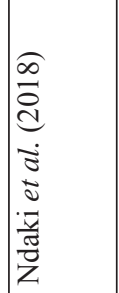 & 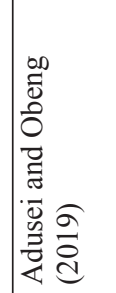 & 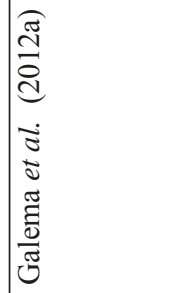 \\
\hline
\end{tabular}




\begin{tabular}{|c|c|c|c|c|c|c|c|c|c|c|}
\hline 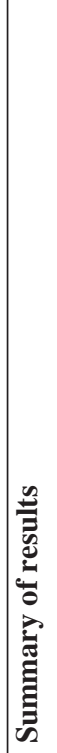 & 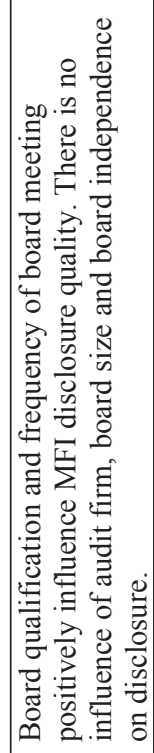 & 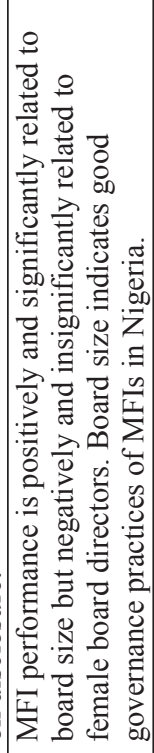 & 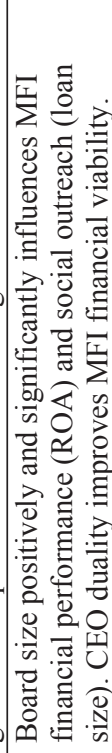 & 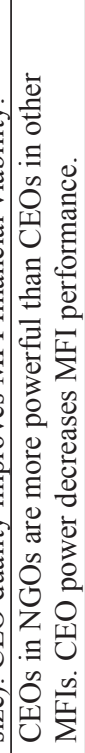 & 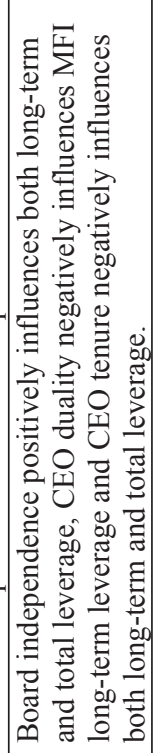 & 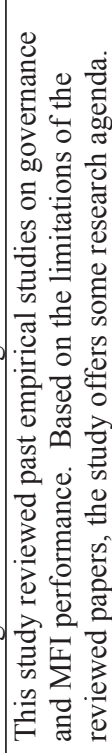 & 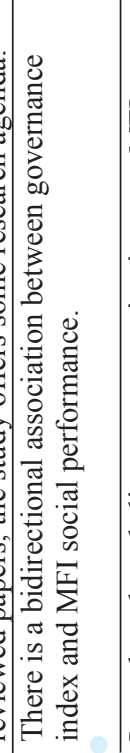 & 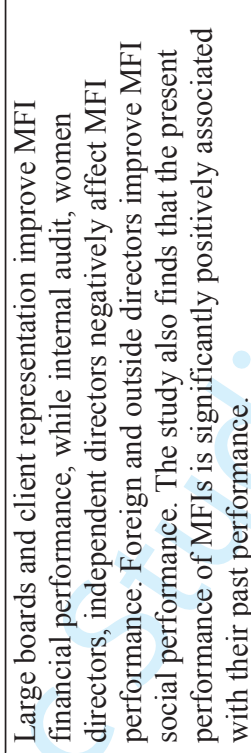 & 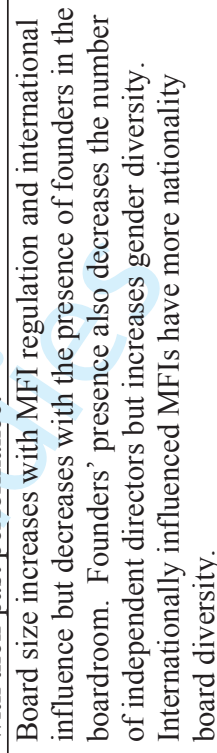 & 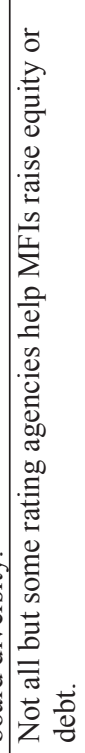 \\
\hline 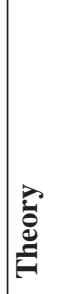 & 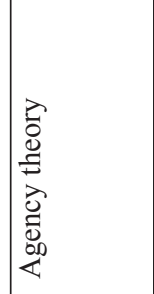 & 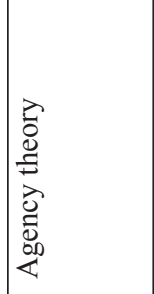 & 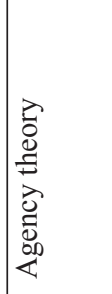 & 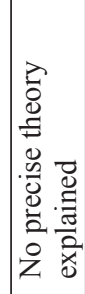 & 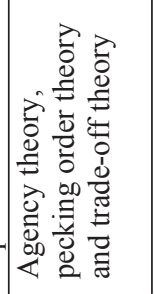 & 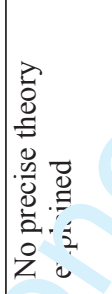 & 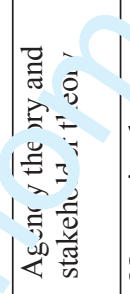 & 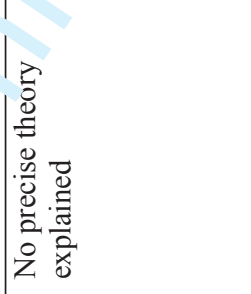 & 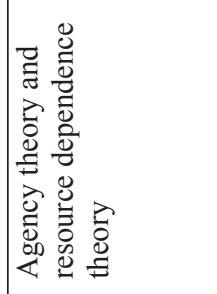 & 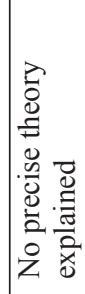 \\
\hline 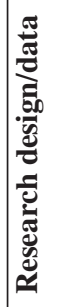 & 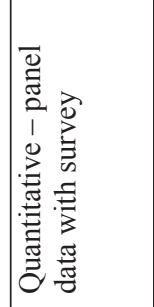 & 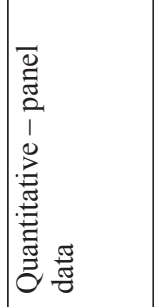 & 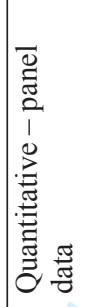 & 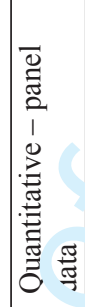 & 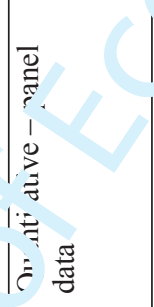 & 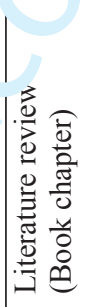 & 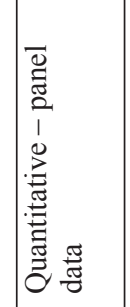 & 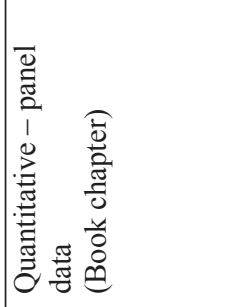 & 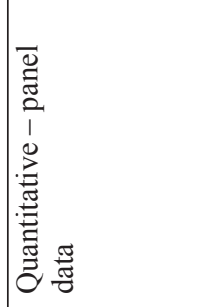 & 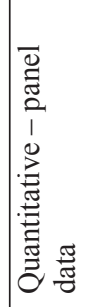 \\
\hline 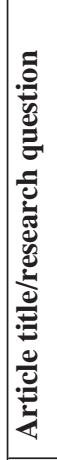 & 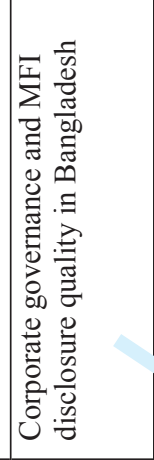 & 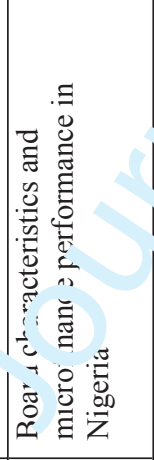 & 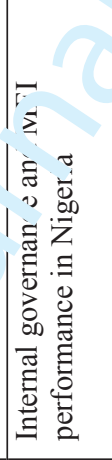 & 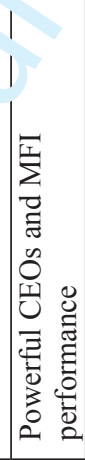 & 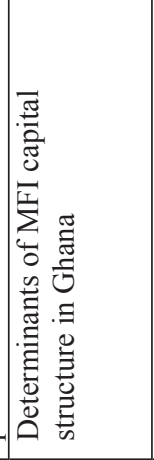 & 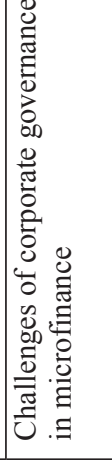 & 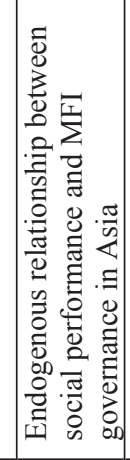 & 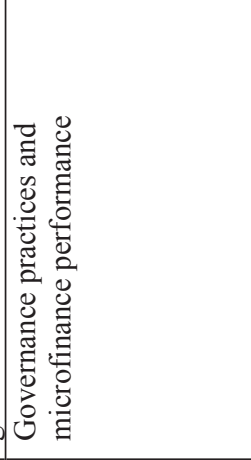 & 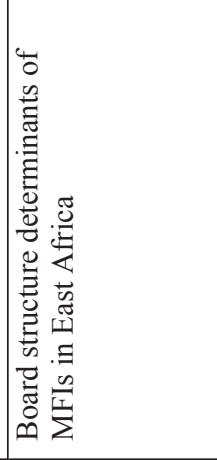 & 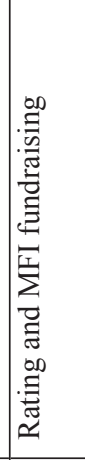 \\
\hline 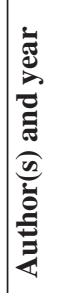 & 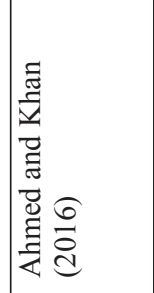 & 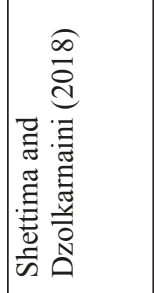 & 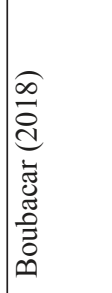 & 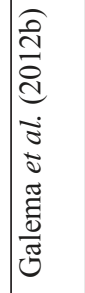 & 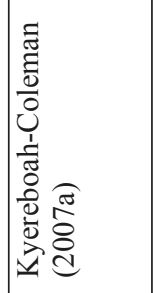 & 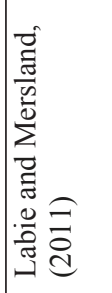 & 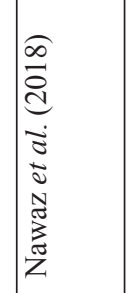 & 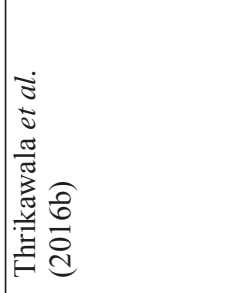 & 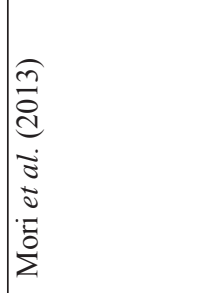 & 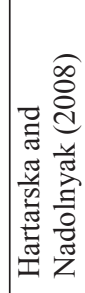 \\
\hline
\end{tabular}

m 